SAND94-2605

Unlimited Release

Printed October 1994

Distribution

Category UC- $=1350$

\title{
BATTERY ENERGY STORAGE FOR UTILITY APPLICATIONS: PHASE I - OPPORTUNITIES ANALYSIS
}

Paul C. Butler, Manager

Storage Batteries Department

Sandia National Laboratories

Albuquerque, New Mexico 87185

\begin{abstract}
One of the goals of the Utility Battery Storage Systems (UBS) Program is to characterize potential electric utility applications for battery energy storage and their economic benefit. The UBS program is conducted by Sandia National Laboratories and sponsored by the U.S. Department of Energy's Office of Energy Management. An initial analysis was performed to identify specific utility applications, to develop engineering requirements for each, to identify entry markets for specific battery technologies, and to assess national-level benefits for each application. Input was provided by representatives from utilities, battery and battery systems manufacturers, consultants, and UBS staff. The results of this study are presented in this report.
\end{abstract}




\section{DISCLAIMER}

This report was prepared as an account of work sponsored by an agency of the United States Government. Neither the United States Government nor any agency thereof, nor any of their employees, make any warranty, express or implied, or assumes any legal liability or responsibility for the accuracy, completeness, or usefulness of any information, apparatus, product, or process disclosed, or represents that its use would not infringe privately owned rights. Reference herein to any specific commercial product, process, or service by trade name, trademark, manufacturer, or otherwise does not necessarily constitute or imply its endorsement, recommendation, or favoring by the United States Government or any agency thereof. The views and opinions of authors expressed herein do not necessarily state or reflect those of the United States Government or any agency thereof. 


\section{DISCLAIMER}

Portions of this document may be illegible in electronic image products. Images are produced from the best available original document. 


\section{EXECUTIVE SUMMARY}

An analysis has been performed to characterize the capabilities and opportunities for batteries to provide energy storage options for electric utilities that result in significant benefits to the utilities and the nation. This study, entitled "Phase I - Opportunities Analysis," was a first step in defining the potential application requirements, preliminary benefits, and costs of battery energy storage. Utility representatives, battery and battery system developers, knowledgeable industry consultants, and national laboratory staff were involved. Five specific objectives were addressed during the analysis. The significant results of the study are summarized below.

Thirteen technically feasible applications of battery storage for the electric utility industry were identified. For each application, the importance of the function to electric utilities was ranked, power and energy requirements were identified, and a duty cycle was defined. This information will be an essential tool for utilities and battery developers who need to evaluate the merits of battery technologies for specific applications.

This study concluded that a single battery system can simultaneously satisfy the requirements of more than one of the thirteen applications. The battery system that the Puerto Rico Electric Power Authority (PREPA) is installing for frequency regulation and spinning reserve is an example of this capability. Many combinations of mutually compatible applications exist, and no unique combination defines an optimum design goal for a battery system. Rather, for each utility, a battery manufacturer, the system integrator, or the utility must identify and evaluate the potential needs that the utility and its customers may have, and select a system optimized for those needs. From the 13 individual applications, three types of multiple applications were defined.

A further analysis was performed to identify the best applications or combinations of applications for each of the battery technologies being considered for use as the energy storage component. Presently, three battery technologies have been selected as the prime candidates based on their attractive characteristics and known deficiencies:

- Valve-Regulated Lead-Acid (VRLA)

$\checkmark$ Sodium/Sulfur

$\checkmark$ Zinc/Bromine 
The important conclusions regarding battery technologies that can be gained from this study are:

(1) The VRLA technology has the potential to optimally or adequately satisfy most of the defined utility energy storage applications. Its primary deficiency is with those applications that place importance on footprint and portability.

(2) The advanced batteries (sodium/sulfur and zinc/bromine) favorably complement the near-term VRLA option primarily for those applications where higher energy capacity is required (duration is $\geq 1$ hour) and footprint/portability are important.

The potential benefits and market size for battery energy storage within electric utilities were analyzed. Results indicate that the market could be very large. In a previous study, Sandia National Laboratories (SNL) estimated that generation and transmission applications could represent $\$ 17.2 \mathrm{~B}$ in national benefits. In this study, the benefits for battery storage were found to be significantly higher than the previous estimates. Further analysis is necessary to translate the potential national benefits of about $\$ 57 \mathrm{~B}$ into a definitive market estimate.

Specific applications, duty cycles, and performance requirements of battery storage systems are described. In addition, this report documents, for the first time, how characteristics of battery types compare to requirements of utility applications. A method is outlined that can prevent disparity between quoted "costs" and ultimate battery system "price" and offers preliminary estimates and recommendations for further analysis of national benefits and market size. As the first comprehensive collection of this information, this report will provide a starting point to improve understanding of utility battery storage applications and communication about them. Response from the readers of this report is solicited as input to the next iteration (Phase II) of the Opportunities Analysis that will be started in about one year. This feedback will assist in the refinement of technical and economic understanding of the role of battery storage in the utility industry. Increased understanding will help promote appropriate development and more rapid commercialization of utility battery storage systems. 


\section{TABLE OF CONTENTS}

EXECUTIVE SUMMARY $\ldots \ldots \ldots \ldots \ldots \ldots \ldots \ldots \ldots \ldots \ldots \ldots \ldots \ldots \ldots \ldots$

TABLE OF CONTENTS $\ldots \ldots \ldots \ldots \ldots \ldots \ldots \ldots \ldots \ldots \ldots \ldots \ldots \ldots \ldots$ iii

1. INTRODUCTION $\ldots \ldots \ldots \ldots \ldots \ldots \ldots \ldots \ldots \ldots \ldots \ldots \ldots \ldots \ldots \ldots$

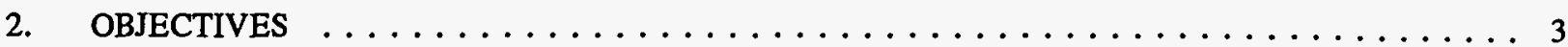

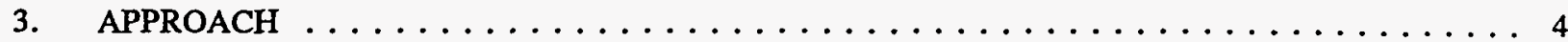

4. IDENTIFICATION AND RANKING OF APPLICATIONS $\ldots \ldots \ldots \ldots \ldots \ldots \ldots$

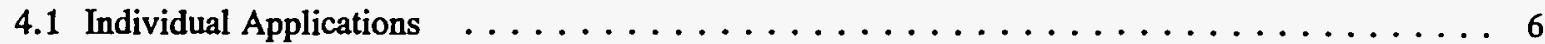

4.2 Multiple Applications $\ldots \ldots \ldots \ldots \ldots \ldots \ldots \ldots \ldots \ldots \ldots \ldots \ldots$

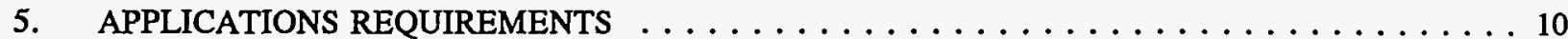

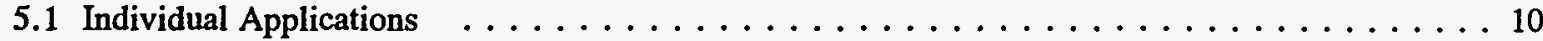

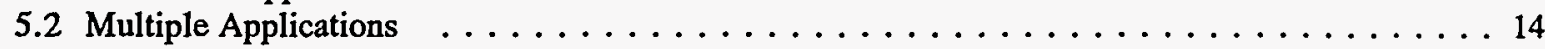

6. APPLICATION SELECTION FOR SPECIFIC BATTERY SYSTEMS $\ldots \ldots \ldots \ldots \ldots \ldots$

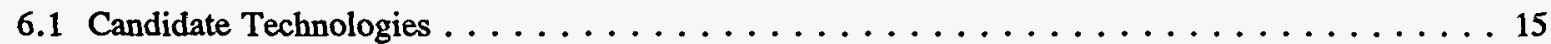

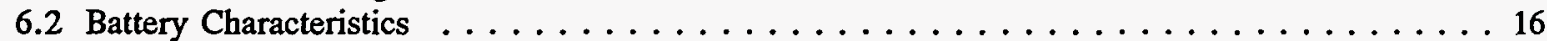

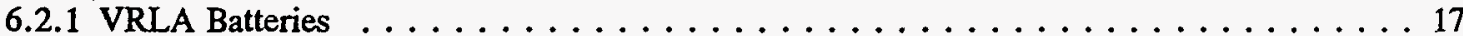

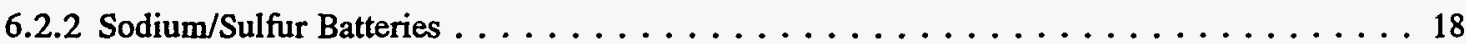

6.2 .3 Zinc/Bromine Batteries . . . . . . . . . . . . . . . . . . . . 19

6.3 Battery Compatibility with Individual Applications $\ldots \ldots \ldots \ldots \ldots \ldots \ldots \ldots \ldots$

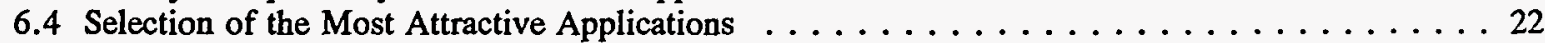

7. POTENTIAL MARKET SIZE AND BENEFITS TO UTILITIES AND THE NATION $\ldots \ldots \ldots 23$

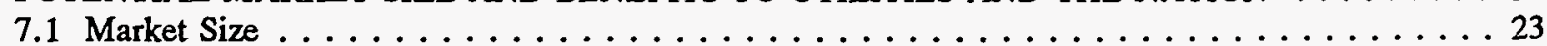

7.2 Assumptions for Benefits Estimates for Each Application $\ldots \ldots \ldots \ldots \ldots \ldots \ldots$

8. COST ESTIMATION FOR UTILITY BATTERY STORAGE SYSTEMS $\ldots \ldots \ldots \ldots \ldots \ldots$

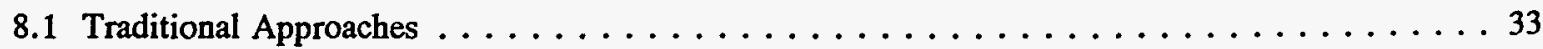

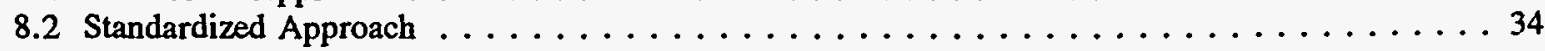

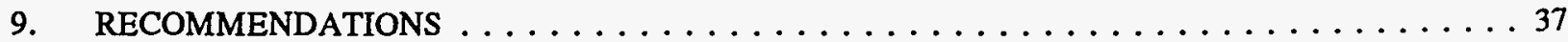

APPENDIX A: FACT SHEETS FOR 13 UTILITY APPLICATIONS OF BATTERY ENERGY

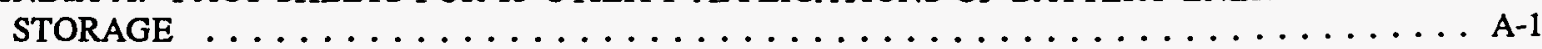

APPENDIX B: SCHEMATIC ILLUSTRATIONS OF BATTERY SYSTEM RESPONSES TO THREE

GROUPS OF MULTIPLE APPLICATIONS $\ldots \ldots \ldots \ldots \ldots \ldots \ldots \ldots \ldots \ldots$ 


\section{INTRODUCTION}

The Utility Battery Storage Systems (UBS) Program is supported by the U.S. Department of Energy (DOE) and conducted by Sandia National Laboratories (SNL). The mission of the UBS Program is to assist industry in developing cost-effective battery storage systems as a utility resource option by the year 2000 . To accomplish this mission, the UBS Program includes activities in systems analysis, subsystems engineering, system integration, field evaluation, and industry outreach. A key objective of the analytical activities is to identify and specify utility applications of battery storage and to quantify the benefits to utilities and the nation.

During the last five years, analytical and technology development activities of the UBS have reshaped traditionally held concepts of the value and application of battery energy storage in the electric utility grid. During this period, the analytical activity of the UBS identified an expanded range of new applications of battery energy storage and showed that battery storage systems could play a "multi-application" role in the utility grid. At the same time, the technology development and system integration activities were breaking new ground in the design of battery systems with a shift toward smaller size, modular systems that were significantly different than existing battery systems.

At this juncture, it is important to pull together these innovations and examine the collective significance to all the activities of the UBS. This task is called the Opportunities Analysis and this report contains the results of the first phase. The economic benefits at the national level are characterized. Where information was available, this includes the market size, timing, and specific applications. System-level requirements for each application are identified, including power, energy, and duty cycle, along with any special needs, such as power quality and siting constraints. Finally, there is a selection of specific battery technologies for utility applications, matching the applications requirements to the performance of each of the three battery technologies being developed by the UBS: valveregulated lead-acid, sodium/sulfur, and zinc/bromine. 
Aside from the important results of the Phase I activity, the process also led to the definition and graphic representation of the duty cycles expected for each utility application. This represents a first-of-a-kind attempt at visualizing the specific duty cycle expected from the full range of the utility applications of battery energy storage.

The Phase I study identified the need for additional information to completely satisfy the objectives of the Opportunities Analysis. The most notable deficiency is in the area of identifying market size for each application. The current information is insufficient to estimate the market size with a high degree of confidence, especially from a system supplier's perspective. Activity in Phase II will primarily focus on this need and characterize the near- and long-term utility market size for battery storage systems. 


\section{OBJECTIVES}

Through the UBS Program, DOE is responding to the issues that must be resolved to fully realize the benefits of utility battery energy storage. Program activities include development of batteries, power electronics, and control systems, and reduction of their costs. Other efforts involve the integration and testing of these components into systems. The success of these activities depends on understanding utilities' needs, technologies' capabilities, and the benefits possible from matching the needs with the capabilities. The Opportunities Analysis is a step in the process of gaining such understanding.

Phase I efforts had the following five specific objectives:

- Identify and rank potential utility applications for battery energy storage

- Define application requirements for battery energy storage systems

- Identify the best applications of candidate battery technologies

Assess the potential market size and potential benefits of battery energy storage to utilities and the nation

Establish a standardized cost breakdown for battery storage systems

Each of these objectives will carry the UBS Program closer to its overall mission of developing utility battery storage as an economically attractive resource option by the year 2000. 


\section{APPROACH}

To successfully perform this analysis, direct involvement of critical stakeholders was required. The vehicle that was used consisted of two working meetings with the following selected individuals, each representing a different important stakeholder:

\section{Electric Utilities}

Ed Arguello - Public Service of New Mexico

Bob Scheffler - Southern California Edison

Rick Winter - Pacific Gas \& Electric

Steve Chapel - Electric Power Research Institute

Battery Industry

Phil Eidler - Johnson Controls, Incorporated

Mike Hinga - Delco-Remy

George Hunt - GNB Industrial Batteries

Al Koenig - Silent Power, Incorporated

Jim Rasmussen - Silent Power, Incorporated

Sandia National Laboratories

Abbas Akhil

Jeff Braithwaite

Paul Butler

Nancy Clark

Garth Corey

Rudy Jungst

Lana Lachenmeyer

\section{Consultants}

Jon Hurwitch - Energetics, Incorporated

Rajat Sen - R. K. Sen, Incorporated

Paula Taylor - Energetics, Incorporated

Hank Zaininger - Zaininger Engineering Company

During the initial meeting held in October of 1993, the group assessed the present state of knowledge relative to the five objectives, identified important deficiencies, and prepared an action plan to address each deficiency. During the second meeting in February of 1994, the entire team reassembled to review the new information and reach a consensus. 
The remainder of this report describes these findings. A few of the gaps remaining after the second meeting were filled by SNL staff and consultants and a few more, as noted in the report, still remain open. 


\section{IDENTIFICATION AND RANKING OF APPLICATIONS}

\subsection{INDIVIDUAL APPLICATIONS}

Thirteen individual applications were identified with potential value to utilities that battery energy storage can perform. Following are the two criteria used to select these applications.

(1) the perceived prevalence of need for the application across the nation, and

(2) the potential technical and economic benefits for utilities.

For utility battery energy storage, the important requirements associated with each application include:
$\checkmark$ power
energy
- cycle frequency
- discharge duration
- duty cycle
$\checkmark$ footprint and portability constraints

The applications were grouped into three categories (Generation, Transmission \& Distribution, and Customer Service), and ranked as either high or moderate value to the utilities. Any low-value applications were eliminated from consideration during the selection process. The following list includes the name, the rank assigned, and a brief description for the 13 selected applications. Each application is discussed in more detail in Appendix A.

\section{Generation}

Spinning Reserve (High Value) - generation capacity that a utility holds in reserve to prevent interruption of service to customers in the event of a failure of an operating generating station. 
Generation Capacity Deferral (High Value) - ability of a utility to postpone installation of new generating facilities by supplementing the existing facilities with another resource.

Area/Frequency Control (High Value) - ability for grid-connected utilities to prevent unplanned transfer of power between themselves and neighboring utilities (Area Control) and ability for isolated utilities to prevent the frequency of the electricity that they produce from deviating too far from $60 \mathrm{~Hz}$ (Frequency Control).

Renewables (High Value) - applications through which renewable power is available during peak utility demand (Coincident Peak) and available at a consistent level (Firming).

Load Leveling (Moderate Value) - storage of inexpensive off-peak power for dispatch during relatively expensive on-peak hours.

\section{Transmission \& Distribution}

Transmission Line Stability (High Value) - ability to keep all components on a transmission line in sync with each other and prevent system collapse.

Voltage Regulation (Moderate Value) - ability to maintain the voltages at the generation and load ends of a transmission line within 5 percent of each other.

Transmission Facility Deferral (High Value) - ability of a utility to postpone installation of new transmission lines and transformers by supplementing the existing facilities with another resource.

Distribution Facility Deferral (High Value) - ability of a utility to postpone installation of new distribution lines and transformers by supplementing the existing facilities with another resource. 


\section{Customer Service}

Customer Demand Peak Reduction (High Value) - storage of off-peak power for a customer to dispatch during greatest on-peak demand as a way to reduce monthly demand charges.

Transit System Peak Reduction (Moderate Value) - storage of off-peak power for a transit system to dispatch during rush hour as a way to reduce monthly demand charges and to relieve the utility of a large demand burden.

\section{Reliability, Power Quality, Uninterruptible Power Supply - Small Customer}

(High Value) - ability to prevent voltage spikes, voltage sags, and power outages that last for a few cycles (less than one second) to minutes from causing data and production loss for customers with demands less than $1 \mathrm{MW}$.

\section{Reliability, Power Quality, Uninterruptible Power Supply - Large Customer (High Value) - ability to prevent voltage spikes, voltage sags, and power outages that last for periods of a few cycles (less than one second) to minutes from causing data and production loss for customers with demands more than $1 \mathrm{MW}$.}

Segregation of the applications into groups is an organizational tool, and not a segregation of battery system functions. In fact, as discussed in the following section of this report, a battery system is most valuable to a utility when it performs multiple functions in more than one of these groups of applications. 


\subsection{Multiple Applications}

From the 13 individual applications, groups of multiple applications were constructed by identifying combinations of applications that would offer the greatest benefits to a utility and that a single battery system "product" could perform. These groups include the following:

- Group I: $\quad$ Spinning Reserve, Load Leveling, Generation Capacity

Deferral, and Area \& Frequency Regulation

- Group II: Distribution Facility Deferral and Voltage Regulation

Group III: $\quad$ Customer Reliability and Customer Demand Peak Shaving 


\section{APPLICATIONS REQUIREMENTS}

For each application, the following requirements were identified for the following important battery energy storage parameters: power and storage needs, AC system voltage, converter type, importance of footprint and portability, and the number and distribution of duty cycles. The impact of these parameters on cost, size, and service life was also analyzed.

\subsection{INDIVIDUAL APPLICATIONS}

Table 5.1 summarizes the requirements for battery systems for the 13 candidate utility applications. The rationale used to select the parameters themselves and the values for each is described in the remainder of this section.

Each of the parameters shown in Table 5.1 (power, storage, voltage, converter type, footprint, portability, and cycles/year) impacts the ability of battery and battery system manufacturers to produce storage systems of appropriate size, functionality, and cost.

Power Requirements: Power requirements determine the size of the power conversion system and can influence the size of the battery depending on its power-toenergy ratio. The battery must also be rated so that power drain does not reduce its service life. Therefore, power requirements can impact the size and cost of the battery, the support structure, and the building. Also, high power levels increase the cost of the control and power-handling equipment.

Energy Requirements: Energy requirements typically determine the number and size of needed battery cells. Consideration must be given to any effects of discharge depth on the service life of the battery. Again, the higher battery energy results in increased size and cost of the shelter and racking. 


\begin{tabular}{|c|c|c|c|c|c|c|c|}
\hline \multicolumn{8}{|c|}{ Table 5-1: Summary of Applications Requirements } \\
\hline Applications & $\begin{array}{c}\text { Approx. } \\
\text { Power } \\
\text { (MW) }\end{array}$ & $\begin{array}{c}\text { Approx. } \\
\text { Storage } \\
\text { (hr) }\end{array}$ & $\begin{array}{c}\text { AC Voltage } \\
\left(k V_{o c}\right) \\
\end{array}$ & $\begin{array}{c}\text { Converter } \\
\text { Type }\end{array}$ & $\frac{\text { Cycles }}{\text { Yoar }}$ & $\begin{array}{c}\text { Footprint } \\
\text { (Importance) }\end{array}$ & $\begin{array}{c}\text { Portability } \\
\text { (Importance) }\end{array}$ \\
\hline \multicolumn{8}{|c|}{ Generation Applications } \\
\hline $\begin{array}{l}\text { Spinning } \\
\text { Reserve }\end{array}$ & $10-100$ & 0.5 & $12-138$ & Line & $20-50$ & Medium & Low \\
\hline $\begin{array}{c}\text { Capacity } \\
\text { Deferral }\end{array}$ & $10-100$ & $2-4$ & $12-138$ & Line & $5-100$ & Medium & Medium \\
\hline $\begin{array}{c}\text { Area/Frequency } \\
\text { Regulation }\end{array}$ & 10 & $<1$ & $12-138$ & Line & 250 & Low & Low \\
\hline $\begin{array}{l}\text { Renewables } \\
\text { Applications }\end{array}$ & 1 & $1-4$ & $0.48-12$ & Line & 250 & Medium & Low \\
\hline $\begin{array}{c}\text { Load } \\
\text { Leveling } t\end{array}$ & 100 & $>4$ & $69-765$ & Line & 250 & Medium & Negligible \\
\hline \multicolumn{8}{|c|}{ Transmission \& Distribution Applications } \\
\hline $\begin{array}{c}\text { Transmission } \\
\text { Line } \\
\text { Stability }\end{array}$ & 100 & $<0.01$ & $69-765$ & Self & 100 & Medium & Low \\
\hline $\begin{array}{l}\text { Voltage } \\
\text { Regulation }\end{array}$ & $\begin{array}{c}1 \\
\text { (MVAR) }\end{array}$ & $<0.25$ & $12-34.5$ & Self & 250 & High & High \\
\hline $\begin{array}{c}\text { Transmission } \\
\text { Facility } \\
\text { Deferral }\end{array}$ & 10 & $2-4$ & $12-138$ & Line & $5-20$ & High & Medium \\
\hline $\begin{array}{c}\text { Distribution } \\
\text { Facility } \\
\text { Deferral }\end{array}$ & 1 & $1-3$ & $4-34.5$ & Line & 30 & High & High \\
\hline \multicolumn{8}{|c|}{ Customer Service Applications } \\
\hline $\begin{array}{l}\text { Demand } \\
\text { Peak } \\
\text { Reduction }\end{array}$ & 1 & $1-2$ & $0.48-12$ & Line & $50-500$ & High & Low \\
\hline $\begin{array}{c}\text { Transit } \\
\text { System } \\
\text { Peak Reduction }\end{array}$ & 1 & $1-2$ & $0.48-2.4$ & Line & $250-500$ & Medium & Low \\
\hline $\begin{array}{c}\text { Reliability \& } \\
\text { Power Quality } \\
\text { (<1MW] }\end{array}$ & 0.1 & $<0.25$ & 0.48 & Self & $<10$ & High & Low \\
\hline $\begin{array}{c}\text { Reliability \& } \\
\text { Power Quality } \\
\text { (>1MW) }\end{array}$ & 1 & $1-2$ & $0.48-12$ & Self & $<10$ & High & Low \\
\hline
\end{tabular}

$t$ See definition of Load Leveling on page 7. 
AC System Voltage: The AC system voltage determines the size and cost of the transformer between the power conditioning system and the AC source and load. Voltage requirements also influence the gauge and cost of cabling for the system.

Converter Type: Power conversion systems can be line- or self-commutating. Applications involving black-start capability or phase control require the additional functionality of a self-commutated converter. Although the cost of self-commutated systems are falling, self-commutated converters have traditionally been more expensive.

Cycles/Year: The type and frequency of duty cycle imposed on the battery constitutes the primary effect on its service life. Many factors must be considered, but clearly duty cycle can significantly influence the size, performance, and changeout interval for the battery. Therefore, the number of duty cycles influences the size and cost of batteries, shelter and racking, and the operation and maintenance (O\&M) expenses for the system.

Footprint: As implied above, the physical size of the system affects system cost. However, for many applications, and for some utilities, space availability is very significant factor.

Portability: In some cases, utilities may have a temporary need for storage at a specific site, and portability can significantly increase the value of a battery storage system. Portability considerations also influence the cost of battery systems.

Appendix A contains fact sheets that describe the rationale behind the values for power storage, converter type, and number of cycles/year presented for each application in Table 5.1. Specifically, the following information for each of the thirteen applications is discussed:

schematic plot of a typical load demand that creates the utility need for the application 
$\checkmark$ text description of the application and the rationale for battery storage as an answer to the need

$\checkmark$ power and energy requirements for the application

$\checkmark$ annual number of cycles that the battery system would experience

distribution of cycles throughout the year

$\checkmark$ representation of test cycling for the battery storage

Relative to the AC voltage values in Table 5.1, the potential locations for a battery storage system in the utility or at the customer site determine the AC voltage that the system must accept and deliver. For example, generation applications require a range of $\mathrm{AC}$ voltage of $0.48-765 \mathrm{kV}$, where a battery system at a renewable generation site operates at $0.48 \mathrm{kVac}$, and a battery system for load leveling could be located at a major generating facility and operate at $765 \mathrm{kVac}$. The ranges of AC voltages for Transmission and Distribution Applications and Customer Service applications also depend on placement in the system, with higher voltages close to generation sites or on large transmission lines. Mid-level voltages reflect placement on transmission and distribution lines. Lower voltages apply at distribution facilities or at customer sites. 


\subsection{Multiple Applications}

Requirements for the three multiple application groups were defined by means of an analysis of the requirements for individual applications in each group. Table 5-2 presents a summary of these requirements.

\begin{tabular}{|c|c|c|c|c|c|}
\hline \multicolumn{6}{|c|}{ Table 5-2: Combined Applications Requirements } \\
\hline Group & Applications & $\begin{array}{l}\text { Power } \\
\text { (MW) }\end{array}$ & $\begin{array}{c}\text { Discharge } \\
\text { Duration } \\
\text { (hrs) }\end{array}$ & $\begin{array}{l}\text { Discharge } \\
\text { Depth }\end{array}$ & $\begin{array}{c}\text { Discharge } \\
\text { Frequency } \\
\text { (in a 24-hour period) } \\
\end{array}$ \\
\hline \multirow{3}{*}{1} & \multirow{3}{*}{$\begin{array}{l}\text { Spinning Reserve, } \\
\text { Area/Frequency } \\
\text { Regulation, } \\
\text { Load Leveling, } \\
\text { Generation } \\
\text { Capacity Deferral }\end{array}$} & \multirow{3}{*}{$\begin{array}{l}10- \\
100\end{array}$} & \multirow{3}{*}{$1-3$} & $\begin{array}{c}\text { Shallow } \\
\text { (A/F Regulation) }\end{array}$ & $\begin{array}{l}\text { Continuous charge and } \\
\text { discharge, } 250 \text { weekdays }\end{array}$ \\
\hline & & & & $\begin{array}{c}\text { Medium } \\
\text { (Load Leveling/Gen. } \\
\text { Deferral) }\end{array}$ & $\begin{array}{l}\text { One discharge/charge } \\
\text { cycle, } 250 \text { weekdays }\end{array}$ \\
\hline & & & & $\begin{array}{c}\text { Deep } \\
\text { (Spinning Reserve) }\end{array}$ & $\begin{array}{c}\text { One discharge/charge } \\
\text { cycle, } \\
20-50 \text { days per year }\end{array}$ \\
\hline \multirow{3}{*}{ II } & \multirow{3}{*}{$\begin{array}{l}\text { Distribution } \\
\text { Facility Deferral, } \\
\text { Voltage } \\
\text { Regulation }\end{array}$} & \multirow{3}{*}{1} & \multirow{3}{*}{$1-3$} & $\begin{array}{c}\text { Shallow } \\
\text { (Voltage Regulation) }\end{array}$ & $\begin{array}{l}\text { Minimal storage for VAR } \\
\text { injection, } 250 \text { weekdays }\end{array}$ \\
\hline & & & & $\begin{array}{c}\text { Medium } \\
\text { ((Distribution Facility } \\
\text { Deferral) }\end{array}$ & $\begin{array}{c}\text { One discharge/charge } \\
\text { cycle, less than } 30 \text { days } \\
\text { per year }\end{array}$ \\
\hline & & & & $\begin{array}{c}\text { Deep } \\
\text { (Distribution Facility } \\
\text { Deferral) }\end{array}$ & $\begin{array}{c}\text { One discharge/charge } \\
\text { cycle, less than } 30 \text { days } \\
\text { per year }\end{array}$ \\
\hline \multirow[t]{3}{*}{ III } & \multirow{3}{*}{$\begin{array}{c}\text { Reliability (UPS), } \\
\text { Power Quality, } \\
\text { Peak Shaving }\end{array}$} & \multirow{3}{*}{$0.1-1$} & \multirow{3}{*}{$1-2$} & $\begin{array}{c}\text { Shallow } \\
\text { (Power Quality \& } \\
\text { Reliability) }\end{array}$ & $\begin{array}{c}\text { One discharge/charge } \\
\text { cycle, less than } 20 \text { days } \\
\text { per year }\end{array}$ \\
\hline & & & & $\begin{array}{l}\text { Medium } \\
\text { (Reliability) }\end{array}$ & $\begin{array}{c}\text { One discharge/charge } \\
\text { cycle, less than } 20 \text { days } \\
\text { per year }\end{array}$ \\
\hline & & & & $\begin{array}{c}\text { Deep } \\
\text { (Peak Shaving) }\end{array}$ & $\begin{array}{l}\text { One-two charge/discharge } \\
\text { cycles, } 250 \text { days per year }\end{array}$ \\
\hline
\end{tabular}

values in this column reflect order of magnitude of power that combined applications require

Appendix B presents schematic graphical illustrations of battery system responses to the multiple application demands during a week that requires the system to perform all of its functions. 


\section{APPLICATION SELECTION FOR SPECIFIC BATTERY SYSTEMS}

\subsection{Candidate Technologies}

This section presents the results of an analysis performed to identify the best applications or combinations of applications for all three candidate battery technologies. Three battery technologies have been selected as the prime candidates for utility-energy storage (UES) based on their attractive characteristics and known deficiencies:

- Valve-Regulated Lead-Acid (VRLA)

- Sodium/Sulfur

- Zinc/Bromine

All three candidates are undergoing engineering development within the UBS Program to improve the benefits that battery storage can provide to utilities. To be successful, the battery or energy-storage subsystem needs lower costs, higher performance, and better integration with the other system components than is currently available. For the near term, an improved VRLA battery technology is being developed that will match or exceed the performance of flooded lead-acid batteries at a cost equal to or lower than the flooded leadacid battery without sacrificing the inherent VRLA advantages (maintenance free, spill and leak proof, no hydrogen hazard during charge, compact installation). Some types of VRLA batteries are commercially available today and already have the performance capability to satisfy many battery storage applications. As such, the eventual large-scale use of VRLA in utility energy storage has relatively low development risk and practically zero production risk.

To progress the market enhancement goal even further, advanced battery technologies are being developed. As will be shown below, the primary motivation for this activity is the potential to more optimally satisfy the high energy applications with a storage duration of $\geq 1$ hour, especially if volume/footprint limitations exist and/or transportability is desired. To illustrate this benefit, a completely integrated $2 \mathrm{MW} / 4 \mathrm{MWh}$ sodium/sulfur system (battery, PCS, controls) can be accommodated within six or seven standard Seabox 
containers (or tractor trailers). A similarly configured system that uses VRLA batteries would require two to three times as many seabox containers or trailers.

Although a number of candidate advanced battery technologies exist that are being developed with both private and public funding, zinc/bromine and sodium/sulfur have the best chance to provide the desired benefits. Neither technology has the same set of obstacles to overcome because two types of batteries are represented: ambient flow and high temperature. In contrast to the VRLA technology, the advanced sodium/sulfur and zinc/bromine technologies are presently in the product engineering phase of development with commercialization probable by the year 1998 to 2000 . Prototype advanced batteries have been built and automated pilot production facilities exist. Although the potential for low cost and long life have been demonstrated, both of these key features will not be proven until the actual commercialization phase is entered. Also, of note is that a relatively low initial battery cost is considered to be mandatory for utility energy storage applications, a feature common to all three candidates and one that to date has precluded consideration of other rechargeable battery technologies, such as nickel/hydrogen and nickel/cadmium.

The remainder of this section presents the results of an analysis to identify the best applications or combination of applications for each candidate battery technology: VRLA, sodium/sulfur, and zinc/bromine.

\subsection{Battery Characteristics}

The battery characteristics that were used in selecting attractive applications for each of the three candidate battery technologies are listed separately below. A brief description of the technology precedes each list. 


\subsubsection{VRLA Batteries}

The sealed, maintenance-free VRLA battery has three components that the wellknown flooded lead-acid battery does not have. The VRLA battery (1) is a completely sealed battery to prevent water loss or release of gases during charging and ingress of oxygen from the outside environment; (2) has a pressure relief vent valve incorporated that permits a positive internal pressure, but prevents excessive pressure build up during high rate charging or overcharging that could cause leaks; and (3) has an immobilized electrolyte that allows gas migration inside the battery that is necessary for the desired recombination reactions to occur. Similar to other battery technologies, cells or modules are connected in series to form strings at full system voltage. Strings can be linked in parallel to deliver the desired power and energy if a single string is not adequate.

\section{Advantages:}

- familiar technology

- known performance characteristics

- excellent power density

- capability to accommodate low to high rate discharge and pulse charge

- proven standby capability

- existing production/marketing infrastructure

- demonstrated low cost (less than $\$ 200 / \mathrm{kWh}$ )

- maintenance free at cell level

- relatively flat voltage discharge profile

Disadvantages:

- low energy density

- susceptible to lower service life if frequently deeply discharged

- thermal management required if ambient temperature is elevated or discharge rate is high 


\subsubsection{Sodium/Sulfur Batteries}

Sodium/sulfur cell and battery configurations are relatively simple. Monopolar, cylindrical cells are connected in series-parallel configurations to form a module or subbattery. The cells composing a discrete battery configuration are placed within an effective thermal enclosure because the internal battery operating temperature must be maintained at $320^{\circ} \mathrm{C}$ to $360^{\circ} \mathrm{C}$. To ensure reliability, cells are hermetic and the interconnections are welded, factors that preclude any maintenance at less than the sub-battery level.

Advantages:

- high usable energy density (gravimetric and volumetric)

- low cost (detailed cost estimates at $\$ 150-200 / \mathrm{kWh}$ )

- high energy efficiency

- maintenance free at battery level

- flexible operation (continuous discharge at moderate rate, pulse discharge/charge at high rate, deep depth of discharge)

- insensitivity to ambient conditions and technically straightforward thermal management options

- transportable (based on electric-vehicle battery)

- flat voltage discharge profile

Disadvantages:

- high temperature operation

- costly thermal management system if operated at sustained high power

- inability to service at cell level

- susceptible to damage if frequently thermally cycled below $250^{\circ} \mathrm{C}$

The need to thermally manage this technology is the most important characteristic affecting the selection of utility energy storage applications. The energy required to maintain the high operating temperature can be insignificant if the battery is routinely used (e.g., once per day). In addition, any undesirable thermal cycling can only occur if grid power is lost 
for many hours. Overall, consideration of thermal issues leads to the conclusion that the sodium/sulfur technology is not attractive from a life-cycle cost perspective for those utility energy storage applications in which:

a. operation (charge/discharge cycling) is relatively infrequent because heat loss becomes significant and lower electrical efficiency results;

b. the battery is frequently cooled to ambient temperature, allowing the reactants to freeze;

c. the energy requirement is small (i.e., less than about $5 \mathrm{kWh}$ );

d. the operation is a continuous, high rate discharge at greater than the $\mathrm{C} / 1$ rate.

\subsubsection{Zinc/Bromine Batteries}

The basic components of a zinc/bromine battery include plastic battery stacks, reservoirs for storing reactants, and pumps for transporting reactants to and from the stacks. This technology is classified as "aqueous flow" because the reactants are solubilized and transported in aqueous solution. During discharge, zinc and bromine react to produce zinc bromide. During charging, the zinc bromide is electrolyzed to produce metallic zinc that deposits on the electrode and bromine that is stored as a complex with quaternary ammonium salts in the external tanks. The electrolytes that are pumped through the cathode and anode compartments of the cell during operation are different and are kept apart by a semipermeable separator between the electrodes.

Advantages:

- good gravimetric energy density (compared to VRLA)

- low cost (plastic and carbon construction - projected at $\$ 150 / \mathrm{kWh}$ )

- adaptable battery design (power vs. energy)

- flexible operation (complete discharge without damage, wide range of operating temperature, continuous use, moderate rate)

- transportable

- modular for servicing ease 
Disadvantages:

- lower electrical efficiency than VRLA or sodium/sulfur

- potentially high self-discharge rate during standby operation unless response times of minutes are available

- unproven maintenance requirements

- need to periodically strip all zinc from electrode

\subsection{BATTERY COMPATIBILITY WITH INDIVIDUAL APPLICATIONS}

The objective of this part of the Opportunities Analysis was to rank the attractiveness of the 13 battery storage applications described in Section 4 for and between each of the candidate battery technologies. The characteristics listed above together with the information contained in Table 5-1 and Appendix A were used. The qualitative results are shown in Table 6-1. Two important comments should be kept in mind when considering these rankings. First, all three candidate battery technologies can be designed to satisfy the technical requirements of most of the 13 battery storage applications. For these compatibility ratings, however, the principal characteristics of the battery technologies were considered in conjunction with the lowest cost design (capital and operating). For example, a sodium/sulfur battery system could be designed for spinning reserve use. However, a significant portion of the battery cost would have to be allocated to a high-performance thermal management system and the overall heat loss would significantly degrade energy efficiency. Secondly, the expectation is that most battery systems connected to a utility grid will be used to simultaneously satisfy multiple applications. However, for some utilities the entry battery storage systems may have to be justified for a single application. Therefore, knowledge of the battery compatibility with individual applications is helpful.

Several important conclusions can be gained from this ranking:

- The VRLA technology has the potential to optimally or adequately satisfy most of the battery storage applications. Its primary deficiency is with those applications that place importance on footprint and portability. 


\begin{tabular}{|c|c|c|c|}
\hline Table 6-1. Compatib & $\begin{array}{l}\text { ttery } \\
\text { tions }\end{array}$ & nologies wit & Individual \\
\hline Applications & VRLA & Sodium/Sulfur & Zinc/Bromine \\
\hline \multicolumn{4}{|c|}{ Generation } \\
\hline Spinning Reserve & $\checkmark$ & $x$ & $x$ \\
\hline Capacity Deferral & $\checkmark$ & $x$ & $\checkmark$ \\
\hline Area/Frequency Regulation & $\star$ & $\checkmark$ & $\checkmark$ \\
\hline Renewables & $\checkmark$ & $\star$ & $\star$ \\
\hline Load Leveling & $x$ & $x$ & $x$ \\
\hline \multicolumn{4}{|c|}{ Transmission \& Distribution } \\
\hline Transmission Line Stability & $\star$ & $x$ & $x$ \\
\hline Voltage Regulation & $\mathrm{X}$ & $\checkmark$ & $\checkmark$ \\
\hline Transmission Facility Deferral & $\checkmark$ & $\checkmark$ & $\star$ \\
\hline Distribution Facility Deferral & $\checkmark$ & $\checkmark$ & $\star$ \\
\hline \multicolumn{4}{|c|}{ Customer Service } \\
\hline Demand Peak Reduction & $\checkmark$ & $\star$ & $\star$ \\
\hline Transit System Peak Reduction & $\checkmark$ & $\star$ & $\checkmark$ \\
\hline Reliability \& Power Quality (<1MW) & $\checkmark$ & $x$ & $x$ \\
\hline Reliability \& Power Quality (>1MW) & $\checkmark$ & $x$ & $x$ \\
\hline
\end{tabular}

- $\star$ - excellent; $\checkmark$-adequate, but not optimum; $X$ - poor

- The advanced batteries favorably complement the near-term VRLA option primarily for those applications where higher energy is required (duration is $\geq 1$ hour) and footprint/portability are important. If instantaneous standby power is not required, zinc/bromine performs better than sodium/sulfur for the infrequent use applications. Conversely, sodium/sulfur requires less maintenance--an important factor for distributed applications such as renewables.

- Battery storage systems are, in general, not attractive for the large, high duration generation applications (e.g., load leveling) because traditional spinning mechanical technologies are more cost effective. 


\subsection{Selection of the Most attractive Applications}

Using the above compatibility results along with the information in Section 5.3 as a guideline, a determination was made of the most attractive applications (combinations acceptable) for each of the candidate battery technologies. The results are listed in Table 62. As noted previously, some technologies have a non-optimum compatibility with specific applications that can be eliminated in a combination-use mode. For example, this situation certainly applies to the first sodium/sulfur application shown in Table 6-2. Here, the prime application (Customer Demand Peak Reduction) frequently exercises the battery and makes the second, infrequent application (Power Quality) more practical. Conversely, some applications, by the nature of their demands on the system, are mutually exclusive.

\begin{tabular}{|l||}
\hline $\begin{array}{l}\text { Table 6-2: Listing of the Most Attractive Applications for Each } \\
\text { UBS Battery Technology }\end{array}$ \\
\hline \hline \multicolumn{1}{c|}{ Valve Regulated Lead Acid (VRLA) } \\
\hline Area Regulation / Spinning Reserve [Group I] \\
\hline Transmission Line Stability \\
\hline Renewables \\
\hline Customer Demand Peak Reduction / Reliability and Power Quality [Group III] \\
\hline Sodium/Sulfur \\
\hline Customer Demand Peak Reduction / Reliability and Power Quality [Group III] \\
\hline Transit System Peak Reduction \\
\hline Renewables \\
\hline Distribution Facility Deferral / Voltage Regulation [Group II] \\
\hline Zinc/Bromine \\
\hline Transmission Facility Deferral \\
\hline Customer Demand Peak Reduction / Reliability and Power Quality [Group III] \\
\hline Distribution Facility Deferral / Voltage Regulation [Group II] \\
\hline Renewables \\
\hline
\end{tabular}




\section{POTENTIAL MARKET SIZE AND POTENTIAL BENEFITS TO UTILITIES AND THE NATION}

For utilities to consider battery energy storage as a viable commercial resource option, they must be able to quantify its benefits and costs. For manufacturers to invest in developing battery storage for utility applications, they must be reasonably certain of the

potential market. Table 7-1 contains estimates of the dollar value of benefits of applications of utility battery storage market through the year 2010 and lists competing technologies for each application.

\subsection{MARKET SIZE}

One of the deficiencies that this study identified was that estimates of potential market size for battery systems for every application could not be characterized (demonstrated by the "TBDs" in Table 7.1). Projections were made only for Generation Capacity Deferral and Customer Demand Peak Shaving. Efforts to address this deficiency identified a need to develop a consistent methodology for translating applications requirements and benefits into market numbers. The two values that are in the table are preliminary estimates based on published data and engineering judgement. The assumptions underlying the benefit estimates and market size are discussed in Section 7.2.

\subsection{AsSumptions for BENEFITS Estimates fOR EACH APPLICATION}

In December of 1993, SNL published document SAND93-3900, "Battery Energy Storage: A Preliminary Assessment of National Benefits (The Gateway Study)." In the report are estimates of the benefits of six utility applications of battery storage and discussion of the assumptions behind the estimates. The benefits analysis conducted as part of this study employed the same assumptions and methodologies. However, whenever refinements were possible or new utility data were available, the new analysis included them. A relative lack of concrete information and experience with battery storage as a utility option caused heavy reliance on utility trends and the experience of industry experts as bases for 
assumptions. The following discussion details the rationale that supports assumptions behind the estimates reported in Table 7-1. Asterisks appear next to applications included in the Gateway Study.

\begin{tabular}{|c|c|c|c|}
\hline \multicolumn{4}{|c|}{ Table 7-1: Projected Market and Benefits for Utility Battery Energy Storage } \\
\hline Application & Market & $\begin{array}{l}\text { Benefit } \\
\text { (\$B) }\end{array}$ & Competing Technologies \\
\hline Spinning Reserve & TBD & 3.3 & $\begin{array}{c}\text { Existing Generation, Hydro, Compressed } \\
\text { Air Energy Storage }\end{array}$ \\
\hline Generation Capacity Deferral & $4.6 \mathrm{GW}$ & 2.3 & Combustion Turbines \\
\hline Area/Frequency Regulation & TBD & 0.7 & Steam Turbines, Hydro \\
\hline Load Leveling & TBD & 1.3 & $\begin{array}{c}\text { Pumped Hydro, Compressed Air Energy } \\
\text { Storage }\end{array}$ \\
\hline Renewables Applications & TBD & 1.4 & Pumped Hydro, Other Energy Storage \\
\hline \multicolumn{4}{|c|}{ Generation Benefit: } \\
\hline Transmission Line Stability & TBD & 3.2 & $\begin{array}{l}\text { Superconducting Magnetic Energy } \\
\text { Storage, Stabilizers, New Lines }\end{array}$ \\
\hline Voltage Regulation & TBD & 0.4 & Capacitors, Switched Voltage Capacitors \\
\hline Transmission Facility Deferral & TBD & 32 & Lines, Transformers \\
\hline Distribution Facility Deferral & TBD & 3.9 & $\begin{array}{l}\text { Lines, Transformers, Demand-Side } \\
\text { Management, Gensets }\end{array}$ \\
\hline \multicolumn{4}{|l|}{ Transmission and Distribution Benefit: } \\
\hline $\begin{array}{l}\text { Customer Demand Peak Shaving } \\
\text { (\& Transit Systems) }\end{array}$ & $2.5 \mathrm{GW}$ & 3.5 & $\begin{array}{l}\text { Uninterruptible Power Supply, Rates } \\
\text { Capacitors, Load Shed }\end{array}$ \\
\hline $\begin{array}{l}\text { Reliability/Power Quality } \\
\text { (Small and Large Customers) }\end{array}$ & TBD & 5.1 & $\begin{array}{l}\text { Uninterruptible Power Supply, Rates } \\
\text { Capacitors, Load Shed }\end{array}$ \\
\hline \multicolumn{4}{|c|}{ Customer Service Benefit: } \\
\hline Total Benefits from All Applications: & & $\$ 57$ & \\
\hline
\end{tabular}




\section{SPINNING RESERVE ${ }^{*}-\$ 3.3$ B}

In the report, "Benefits of Battery Storage as Spinning Reserve, EPRI-AP-5327," Zaininger showed that spinning reserve benefits equal about 0.4 percent of total production costs for electric utilities. The "Financial Statistics for Investor-Owned Electric Utilities, DOE/EIA-0437" shows that national utility production costs were $\$ 70$ B in 1990 . Therefore, the benefits of battery storage for spinning reserve in 1990 could have been $\$ 280 \mathrm{M}$. With 4 percent inflation, the annual benefits of battery storage for spinning reserve in 1995 could reach $\$ 340 \mathrm{M}$. With a 6 percent discount rate, the value of spinning reserve benefits between 1995 and 2010 would be $\$ 3.3$ B.

\section{Generation Capacity DeferraL * ${ }^{*}$ - $\$ 2.3$ B}

Trends in the U.S. electric utility industry indicate that utilities will have excess capacity for baseload requirements until the year 2000 . However, peaking requirements will cause utilities to add combustion turbines to meet peak loads. After the year 2000, utilities will need to add baseload capacity to accommodate load growth and to offset retirements. Even with these baseload additions, utilities will continue to add peaking capacity. The data in Table A9 of the "DOE/EIA Annual Energy Outlook 1994" illustrates these trends. From that table, the expected combustion turbine/diesel additions to generating capacity are as shown in Table 7-2.

\begin{tabular}{|c|c|c|c|c|c|}
\hline \multicolumn{6}{|c|}{$\begin{array}{c}\text { Table 7-2: Trends in Generation Capacity from Combustion } \\
\text { Turbines and Diesel Engines }\end{array}$} \\
\hline Year: & 1992 & 1995 & 2000 & 2005 & 2010 \\
\hline $\begin{array}{c}\text { Capacity } \\
\text { (GW) }\end{array}$ & 45.6 & $49.4 \dagger$ & 55.7 & 82.0 & 98.8 \\
\hline
\end{tabular}

t Interpolated from 1992 and 2000 values. 
As battery storage gains acceptance with utilities, it will be able to displace an increasing amount of peaking capacity additions. Based on the experience of utility planners, it was assumed that battery systems can displace 5 percent of the planned combustion turbine additions between 1995 and 2000, and 10 percent of the additions between 2000 and 2010 . (These estimates are more conservative than earlier estimates presented in the Gateway Study.) At this rate, the total cumulative peaking capacity displacement by battery energy storage will be $4.6 \mathrm{GW}$. Combustion turbines cost about $\$ 500 / \mathrm{kW}$. Therefore, the benefit of generation capacity deferral from 1995 to 2010 could be $\$ 2.3$ B.

\section{AREA/FREQUENCY REGULATION - \$0.7 B}

Utilities that operate fossil generating units at less than full capacity to accommodate expected load fluctuations could use battery energy storage to control the frequency and transfer of electricity. For many utilities, area/frequency regulation is included in spinning reserve and, for others, hydroelectric power provides such regulation. Based on expertise in utility planning, the assumption was made that area/frequency regulation benefits (that battery energy storage can provide) might be 20 percent of the spinning reserve benefits cited above, or $\$ 0.7 \mathrm{~B}$.

\section{LOAD LEVELING* ${ }^{*}$ \$1.3 B}

When utilities' off-peak demands are significantly lower than peak demands, baseload generating units typically operate at inefficient and expensive partial loads. In utilities with significant differences in incremental fuel costs during on- and off-peak times, battery systems can allow off-peak baseload operation and dispatch the energy during on-peak demand. System studies conducted by SNL for Oglethorpe Power Corporation and SDG\&E ("Specific Systems Studies of Battery Energy Storage for Electric Utilities, SAND93-1754") found that the benefit of improved generation dispatch is approximately 40 percent of the benefit that batteries can yield in spinning reserve. As cited above, the spinning reserve benefits projected between 1995 and 2010 are about $\$ 3.3 \mathrm{~B}$. The results of the SNL system studies suggest that load leveling benefits between 1995 and 2010 could be $\$ 1.3 \mathrm{~B}$. 


\section{RENEWABLES APPLICATIONS - \$1.4 B}

Table A16 of the "DOE/EIA Annual Energy Outlook 1994" projects increasing energy production from wind and solar resources between 1992 and 2010. Table 7-3 summarizes these projections.

\begin{tabular}{|c|c|c|c|c|c|}
\hline \multicolumn{6}{|c|}{ Table 7-3: Energy from Solar and Wind } \\
\hline \hline Year & 1992 & $1995 t$ & 2000 & 2005 & 2010 \\
\hline \hline Wind & 2.91 & & 2.91 & 3.55 & 29.09 \\
\hline Solar & 1.75 & & 2.35 & 3.36 & 4.81 \\
\hline $\begin{array}{c}\text { Total } \\
\text { (Billion } \mathrm{kWh} \text { ) }\end{array}$ & 4.66 & 4.98 & 5.26 & 6.91 & 33.90 \\
\hline
\end{tabular}

t Interpolated form 1992 and 2000 data, assuming linear growth between data points.

Assuming linear growth between data points, the total energy available from wind and solar resources will be 145 billion $\mathrm{kWh}$.

If this energy displaces other energy at $3 \mathrm{c} / \mathrm{kWh}$, the average annual benefit would be $\$ 0.29$ B. With a 6 percent discount rate, the total present worth of the benefit is about $\$ 2.8 \mathrm{~B}$. Based on the experience of utility planners, it is assumed that battery energy storage might be installed in half of these wind and solar systems. During utility peak demand times, utilities could dispatch the battery system to claim 50 percent of the potential displacement benefit or $\$ 1.4$ B. The Photovoltaic Design Assistance Center at SNL published a survey entitled, "Photovoltaic Industry Survey: An Evaluation of the Photovoltaic Battery Market, 1992," Document Number 93-101-RES, that will help refine estimates of benefits and develop market projects for battery system support of photovoltaics.

\section{TRANSMISSION LINE STABILITY - \$3.2 B}

When transmission line instabilities diminish power transfer capability, utilities can install battery storage systems to handle transient load fluctuations. Because battery systems 
increase the effective capacity of transmission lines by the amount that transients would claim, the benefit of battery storage for line stability is a form of transmission capacity deferral. An assumption that 10 percent of the utilities in the United States have significant line stability issues that battery storage could address is based on engineering and business experience with the utility industry. Ten percent of the $\$ 32.4 \mathrm{~B}$ benefit estimated for transmission facility deferral (discussed below) is $\$ 3.2 \mathrm{~B}$.

\section{VOLTAGE REGULATION - \$0.4 B}

Utilities use capacitors to keep voltage at the load-end of distribution systems within a few percentage points of voltage at the generation-end of the line. A typical utility policy might include 0.6 MVAR of capacitors for every MW of load. Battery systems with selfcommutated inverters, installed for other primary applications, can achieve voltage regulation, and displace capacitors and their cost.

At this rate, with a $2 \%$ load growth, the load will increase $13 \mathrm{GW} /$ year, and associated annual capacitor installation would be 7.8 GVAR. As cited in "Integration of Renewable Energy Sources into Electric Power Distribution Systems, Vol. 2, Utility Case Assessments, ORNL-6775/2," capacitors cost between $\$ 10$ and $\$ 120$ per kVAR. Even at $\$ 25 / \mathrm{kVAR}$, capacitors to meet the projected load growth would cost utilities more than $\$ 195 \mathrm{M}$ per year.

Utility planning experience supports an assumption that 20 percent of the utilities in the United States might install self-commutated battery systems for other applications and will be able to displace capacitors. The potential benefits would be $\$ 39 \mathrm{M}$ annually. At a 6 percent discount rate, the present value of these voltage regulation benefits between 1995 and 2010 would be $\$ 0.4 \mathrm{~B}$.

\section{TRANSMISSION FACILITY DEFERRAL * ${ }^{*} \$ 32$ B}

The DOE/Office of Energy Emergencies' "Staff Report on Electric Power Supply and Demand for the Contiguous United States (1989-1998)" DOE/IE-0018, shows that, after 
1986, utilities installed about 0.857 miles of transmission lines (above $22 \mathrm{kV}$ ) for every MW of new generation capacity. That same report shows that utility installations of extra-high voltage (EHV) transmission lines ( $254 \mathrm{kV}$ and above) add mileage at a rate of about 11.5 percent of the $22 \mathrm{kV}$ line installations. The data shown in Table 7-4 are projections for total generation capacity from the "DOE/EIA Annual Energy Outlook 1994."

\begin{tabular}{|c|c|c|c|c|c||}
\hline \multicolumn{6}{|c|}{ Table 7-4: Trends in Total Generation Capacity } \\
\hline \hline Year & 1992 & $1995 t$ & 2000 & 2005 & 2010 \\
\hline \hline Utility & 691.2 & & 709.2 & 723.5 & 740.7 \\
\hline Non-Utility & 12.5 & & 30.8 & 45.1 & 44.5 \\
\hline $\begin{array}{c}\text { Total } \\
\text { (Thousand MW) }\end{array}$ & 703.7 & 717.3 & 740.0 & 768.6 & 785.2 \\
\hline \hline
\end{tabular}

† Interpolated from 1992 and 2000 data, assuming linear growth between data points.

Between 1995 and 2010, the projected increase in generating capacity is 67.9 thousand MW. The associated transmission line installation will be 58.2 thousand miles. With additional EHV installations of 6.7 thousand miles, the total projection reaches 64.9 thousand miles of new transmission lines.

Batteries can defer transmission facilities for the delivery of power to load centers, but cannot defer facilities for wheeling power through the system or to carry power from new generation sites. Therefore, battery storage has the potential to halve future line installations to 32.4 thousand miles. As cited in "Potential Benefits of Battery Storage to Electrical Transmission and Distribution Systems, EPRI GS6681," transmission lines have a range of cost that depends on voltage. For the purpose of this study, an estimate of $\$ 1 \mathrm{M} / \mathrm{mile}$ is being used. Deferral of 32.4 thousand miles of line would represent $\$ 32 \mathrm{~B}$. This estimate of benefits does not include transformers, relays, or other auxiliaries. 


\section{DISTRIBUTION FACILITY DEFERRAL - \$3.9 B}

The largest distribution facility deferral benefits will most likely come from the deferral of new distribution substation transformer additions. A typical utility might add 1.5 MVA of distribution substation transformer capacity per MW of load. If the load grows $13 \mathrm{GW}$ annually, the load increase will require transformer installations at distribution substations of $19.5 \mathrm{GVA} /$ year.

As cited in "Integration of Renewable Energy Sources into Electric Power Distribution Systems, Vol. 2, Utility Case Assessments, ORNL-6775/2." The installed costs of $25 \mathrm{MVA}$ transformers have been $\$ 1 \mathrm{M}$, or more. At a cost of $\$ 1 \mathrm{M} / 25 \mathrm{MVA}$, the annual market for distribution substations transformers between 1995 and 2010 would be $\$ 0.8 \mathrm{~B}$. Industry experience supports the assumption that battery systems might defer half of the necessary substation transformers. The benefit will be $\$ 0.4 \mathrm{~B}$. With a 6 percent discount rate, the present value of the benefits between 1995 and 2010 is $\$ 3.9 \mathrm{~B}$.

\section{Customer (and TRANSIT System) Demand PeAK SHAVING ${ }^{*}-\$ 3.5$ B}

Business and industrial customers' electric utility rates generally include a demand charge for the highest on-peak demand in each billing period. EPRI-AP/EM-5895 indicates that a typical demand charge for a large customer is near $\$ 12 / \mathrm{kW}$. Battery systems can store energy for dispatch during peak demand times, and significantly reduce monthly demand charges.

Page 29 of the "DOE/EIA Annual Energy Outlook 1994" reports that electric utilities spent $\$ 1.2 \mathrm{~B}$ on demand-side management (DSM) programs to reduce peak demands by $25 \mathrm{GW}$ in 1990. The same DOE/EIA document projects expenditures of \$4 B on DSM in 1997. If the ratio of $20.8 \mathrm{GW} / \$ \mathrm{~B}$ remains constant, and DSM expenditures grow linearly between 1995 and 2010, the peak reduction possible from DSM programs will be as shown in Table 7-5. 


\begin{tabular}{|c|c|c|c|c|}
\hline \multicolumn{5}{|c|}{ Table 7-5: } \\
\hline YSM Expenditures \& Peak Reduction \\
\hline \hline Year & 1995 & 2000 & 2005 & 2010 \\
\hline Expenditure (\$B) & 3.2 & 5.2 & 7.2 & 9.2 \\
\hline Peak Reduction (GW) & 67 & 109 & 151 & 193 \\
\hline
\end{tabular}

Battery energy storage is best suited to shaving peaks of short duration. Therefore, battery systems will be appropriate for a relatively small portion of utility customers. As battery energy storage gains acceptance with utilities and their customers, it will be installed with greater frequency to provide customer demand peak shaving for commercial, industrial, and transit system customers. Although a full market study of utility customers is necessary to quantify the amount of the market that battery storage could capture, 1 percent of the average market between 1995 and 2000, 2 percent of the average market between 2000 and 2005, and 3 percent of the average market between 2005 and 2010 is probably a conservative assumption. The potential market for battery storage for DSM would be $2.5 \mathrm{GW}$. At $\$ 12 / \mathrm{kW}$, demand peak reduction will be worth $\$ 30 \mathrm{M}$ every month, and $\$ 360 \mathrm{M}$ annually. With a 6 percent discount rate, the present value of this benefit over the 15 -year interval would be $\$ 3.5 \mathrm{~B}$.

\section{Reliability/POWER Quality (LARge AND SMALl Customers) - \$5.1 B}

A recent article in Business Week, April 8, 1991, estimated the annual costs to U.S. industry of power outages at $\$ 26 \mathrm{~B}$. The emergence and growth of power quality groups in utilities within the last decade indicates that utility customers have increasing sensitivity to power quality and reliability issues, and that the costs associated with outages will continue to grow as electronic systems penetrate more facets of industry. Even if constant, outage costs between 1995 and 2010, with 6 percent discount rate, would be $\$ 253$ B.

As battery storage gains acceptance, and as utilities look for new ways to retain industrial customers in the face of retail wheeling, battery storage will be able to reduce a 
growing percentage of that cost. Even 2 percent of the total would be $\$ 5.1 \mathrm{~B}$. For the reasons stated above, this estimate is probably conservative.

As was shown in Table 7-1, the projected benefits to utilities that use battery energy storage in generation applications is $\$ 9 \mathrm{~B}$. Benefits from transmission and distribution are estimated at about $\$ 40 \mathrm{~B}$; benefits from customer service applications are about $\$ 9 \mathrm{~B}$. This projection, already nearly $\$ 58$ B by the year 2010 , will almost certainly increase with additional analysis. Increased understanding from experience and active investigation is uncovering new benefits in transmission and distribution and customer service. The estimates of total benefits to the nation, which include the benefits to utilities, will increase similarly. 


\section{COST ESTIMATION FOR UTILITY BATTERY STORAGE SYSTEMS}

One of the objectives of Phase I of the Opportunities Analysis was the development of a standardized cost breakdown methodology for utility battery storage systems that all interested organizations should use to ensure consistency.

\subsection{Traditional Approaches}

Using the traditional approach, direct comparisons of costs for battery systems are impossible. Table 8-1, which shows the published cost breakdowns for two existing demonstration projects of similar size and technology, illustrates this disparity.

\begin{tabular}{|c|c|c|c|}
\hline \multicolumn{2}{|c|}{$\begin{array}{l}\text { a System Installed by the } \\
\text { Puerto Rico Electric Power Authority }\end{array}$} & \multicolumn{2}{|c|}{$\begin{array}{c}\text { System Installed by the } \\
\text { Southem California Edison Company }\end{array}$} \\
\hline 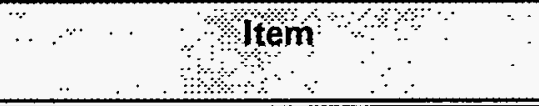 & $\begin{array}{l}\text { Cost } \\
\text { (\$M) }\end{array}$ & Item & $\begin{array}{l}\text { Cost } \\
(\$ M) \\
\end{array}$ \\
\hline Engineering Design & 1.00 & Engineering Design & 6.00 \\
\hline $\begin{array}{c}\text { Battery } \\
\text { (14.1 MWh - flooded lead-acid) }\end{array}$ & 4.50 & $\begin{array}{c}\text { Battery* } \\
\text { (40 MWh - flooded lead-acid) }\end{array}$ & 1.90 \\
\hline $\begin{array}{l}\text { Power Conversion System } \\
\text { (20 MW - GTO) }\end{array}$ & 5.40 & $\begin{array}{l}\text { Power Conversion System } \\
\text { (10 MW - GTO) }\end{array}$ & 4.70 \\
\hline Main Transformer & 0.36 & $?$ & $?$ \\
\hline AC Switchgear & 0.19 & $?$ & $?$ \\
\hline DC Switchgear & 0.65 & $?$ & $?$ \\
\hline Controls & 0.80 & $?$ & $?$ \\
\hline Construction Contract & 4.00 & $?$ & $?$ \\
\hline$?$ & $?$ & Balance of Plant & 0.90 \\
\hline Total & 16.9 & Total & 13.50 \\
\hline
\end{tabular}

- Lead donated to project by the International Lead Zinc Research Organization 


\subsection{STANDARDIZED APPROACH}

The discrepancies shown in Section 8.1 provide strong evidence that a more standardized approach is needed. When the structure and nomenclature of cost breakdowns are uniform, utilities will be better able to assess the costs of systems, and manufacturers will be better able to economically justify their products and services to utilities. In the past, cost estimates for utility battery storage systems have sometimes neglected costs of subsystems components, transportation, financing, and taxes. Unless a cost estimate includes such items, the cost is for a collection of components. Figure 8-1 illustrates the major parts of a utility battery storage system.

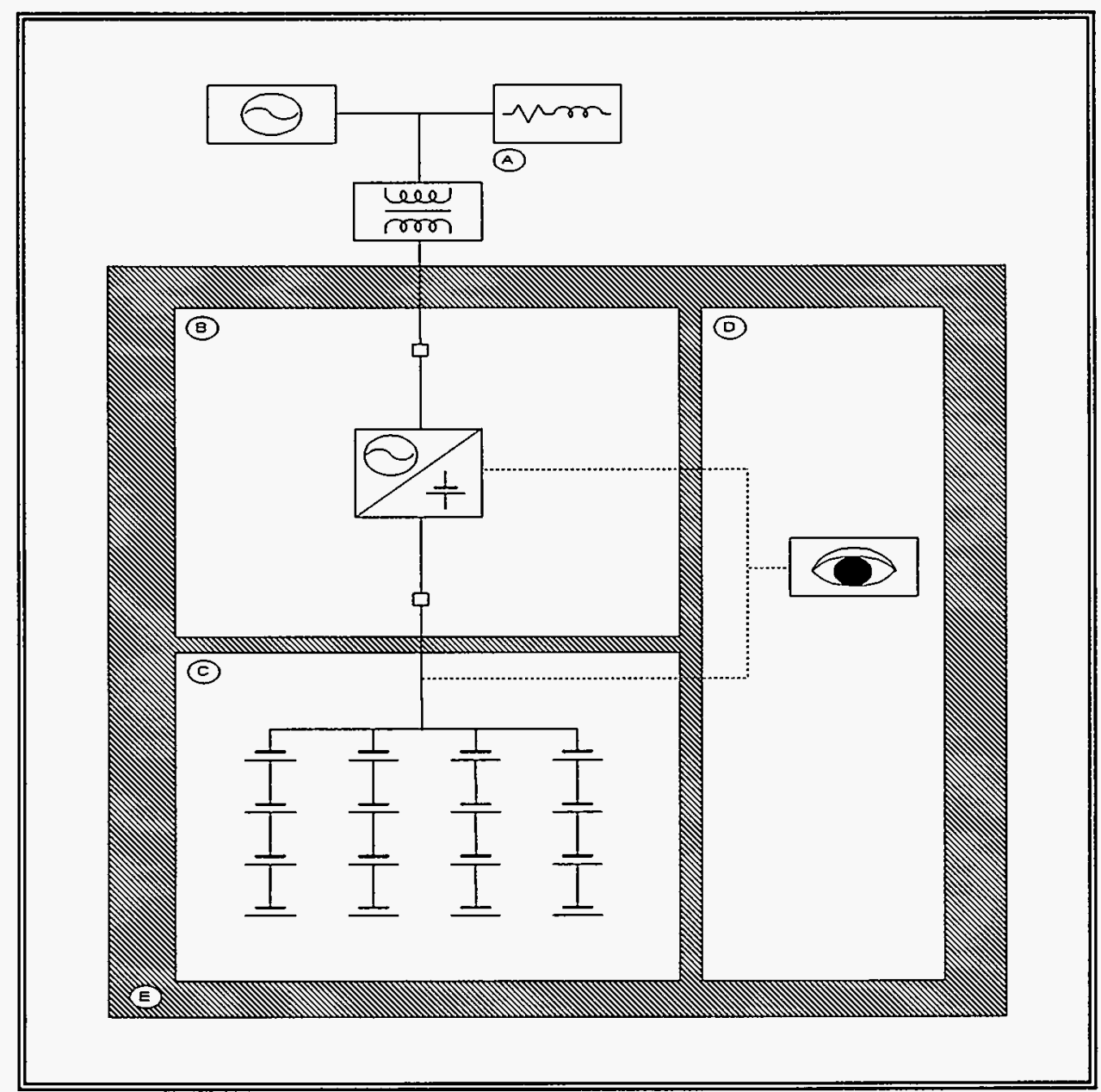

A. AC Source/Load Interface to Battery System

B. Power Conversion System

C. Batteries

D. Monitors and Controls

E. Facilities

F. Financing

G. Transportation

H. Taxes

I. Services

J. Operation \& Maintenance

(F-J not depicted in figure.)

Figure 8-1: Schematic of Cost Components of Utility Battery Storage System 
Table 8-2 details the subcomponents within each part of the battery system and peripheral materials and services associated with this structure.

\begin{tabular}{|c|c|}
\hline $\begin{array}{l}\text { A. AC SOURCEILOAD INTERFACE } \\
\text { TO BATTERY SYSTEM }\end{array}$ & $\begin{array}{l}\text { 1. New lines to serve installation }(\theta .9 ., 4,12,69 \mathrm{kV}) \\
\text { 2. Transformer between utility voltage and battery system AC voltage (e.g., } 69 \mathrm{kV}: 480 \mathrm{v} \text { ) } \\
\text { 3. Protection Devices (e.g., switches, breakers, fuses) }\end{array}$ \\
\hline $\begin{array}{l}\text { B. POWER CONVERSION } \\
\text { SYSTEM: }\end{array}$ & $\begin{array}{l}\text { 1. AC Switchgear/Disconnect } \\
\text { 2. Rectifier/Inverter } \\
\text { 3. DC Switchgear/Disconnect } \\
\text { 4. Protection Devices (e.g., switches, breakers, fuses) }\end{array}$ \\
\hline $\begin{array}{l}\text { C. BATTERIES AND } \\
\text { ACCESSORIES }\end{array}$ & $\begin{array}{l}\text { 1. Electrical } \\
\text { a. Batteries (cells, tanks, membranes) } \\
\text { b. Interconnects } \\
\text { c. Protection Devices (e.g., switches, breakers, fuses) } \\
\text { d. Chargers } \\
\text { 2. Mechanical } \\
\text { a. Racking/Physical Support } \\
\text { b. Watering/Heating/Air and Fluid Pumping Systems } \\
\text { c. Safety Equipment (e.g., ventilation, fire equipment, detectors, respirators, spill } \\
\text { troughs) }\end{array}$ \\
\hline D. MONITORS \& CONTROLS & $\begin{array}{l}\text { 1. Monitors/diagnostics } \\
\text { a. PCS } \\
\text { b. Batteries (strings and cells) } \\
\text { 2. Controls } \\
\text { a. PCS } \\
\text { b. Batteries } \\
\text { c. Protection Devices }\end{array}$ \\
\hline E. FACILTIES & $\begin{array}{l}\text { 1. Foundation and Structure (and associated labor) } \\
\text { 2. Materials } \\
\text { 3. Lighting/Plumbing } \\
\text { 4. Finish Grade/Landscape } \\
\text { 5. Access Road } \\
\text { 6. Grounding/Cabling } \\
\text { 7. HVAC }\end{array}$ \\
\hline \multicolumn{2}{|l|}{ F. FIMARCING } \\
\hline \multicolumn{2}{|l|}{ G. TRANSPORTATION- } \\
\hline \multicolumn{2}{|l|}{ H. TAXES } \\
\hline I. SERVICES & $\begin{array}{l}\text { 1. Project Management } \\
\text { 2. Installation } \\
\text { 3. Studies (e.g., relays, harmonic filters) } \\
\text { 4. Data Gathering/Trending } \\
\text { 5. Permits }\end{array}$ \\
\hline $\begin{array}{l}\text { J. OPERATION AND } \\
\text { MAINTENANCE }\end{array}$ & $\begin{array}{l}\text { 1. Service Contract } \\
\text { 2. Cell/Fluid Recycling/Replacement } \\
\text { 3. Training } \\
\text { 4. Inspections }\end{array}$ \\
\hline
\end{tabular}

* For the turn-key systems evolving, separate costing of these items may not be necessary. However, these items will be part of the specification upon which turn-key vendors bid. 
As noted, some cost groups collapse into a line-item for turn-key systems. However, the detailed breakdown is necessary for specifying the system on which vendors bid. Additional detail will be necessary to allow true comparative costing of systems. However, identifying the appropriate level of detail will require additional analysis that Phase II Opportunities Analysis efforts should include. 


\section{RECOMMENDATIONS}

During the Phase I Opportunities Analysis, a baseline of information was established on which future efforts to quantify battery storage requirements and benefits can build. The results clearly indicate that the present knowledge of key factors regarding battery system costs, market size, and benefits is not adequate and that more work remains. The first task of Phase II efforts should be to solicit, receive, and synthesize detailed comments from industry experts on the Phase I report. With this feedback, subsequent Opportunities Analysis efforts will expand upon information already assembled. Specifically, Phase II activities should have the following focus:

- Develop a more comprehensive and standardized breakdown methodology for battery system costs

Define the market sizes for specific applications and relevant battery systems

- Quantify application-specific benefits to a higher level of confidence

- Define standardized application requirements

Phase II activities will be essential in the identification of the most economical use of battery storage in the electric utility industry and the technological development that will be necessary to support it. The standardized cost breakdown will allow utilities to directly compare the capabilities and costs of battery systems from various vendors. Refined definitions of combined applications will identify design parameters for battery systems for utility applications. An estimate of market size will reduce the risk that manufacturers take to invest in production of those battery systems. More accurate estimates of benefits from utility battery storage will allow utilities to make educated decisions about including battery storage as a resource in their systems. 


\section{APPENDIX A: FACT SHEETS FOR THIRTEEN UTILITY}

APPLICATIONS OF BATTERY ENERGY STORAGE 


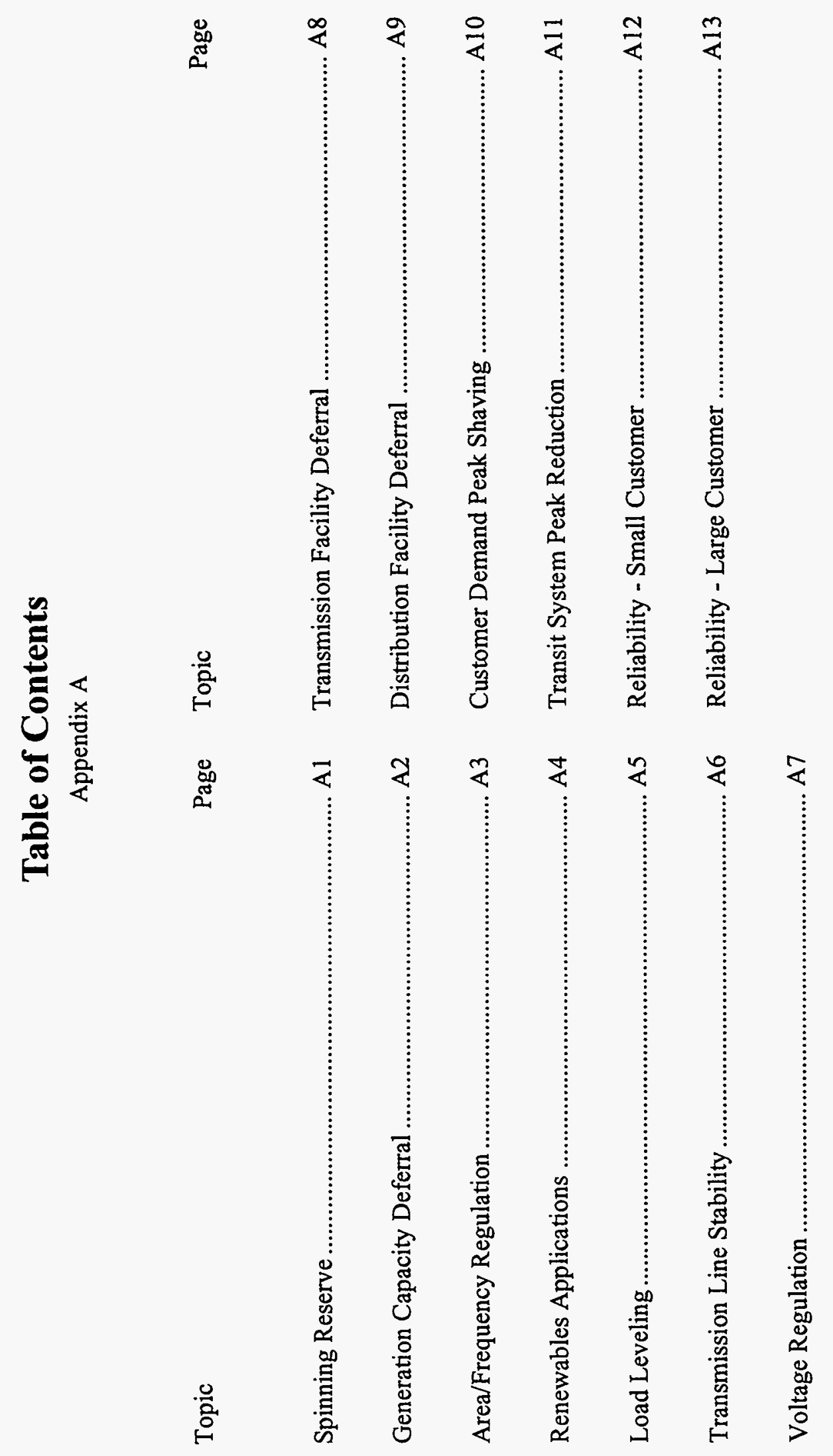




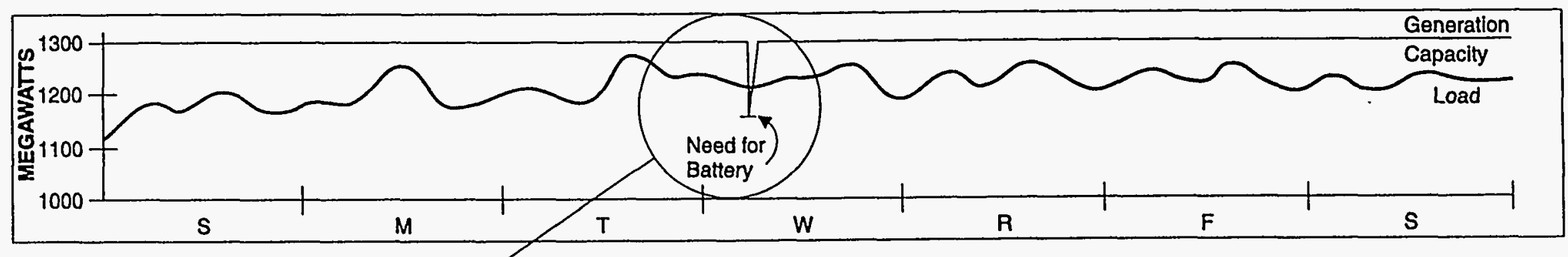

Generation Capacity and Load on a Randomly Selected Week with a Generation Capacity Interruption

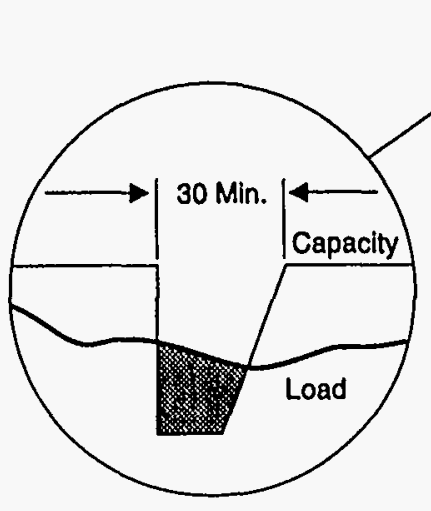

If an electrical generating unit fails, the utility that operates it must draw power from other sources to prevent interruption of service to customers. In an island utility, the available reserve power must equal the

\section{Spinning Reserve}

power output of the largest generating unit in operation. Both island utilities and grid-connected utilities use thermal power plants and combustion turbines (CTs) to provide reserve power. However, the generators must be "spinning" to provide an instantaneous response.

Cold thermal power plants require hours, and CTs require about half-an-hour to get generators spinning. Consequently, utilities operate thermal plants and CTs at less-than-full capacity to have generators spinning and ready to provide reserve power. Battery energy storage can help utilities maintain spinning reserve, reduce or eliminate the need for supplemental power from CTs, and free thermal plants to generate at full capacity (and greater efficiency and economy). Battery systems designed for spinning reserve must replace generation units that fail, and provide power until the utility brings other sources of power on line or repairs the failed unit. Therefore, battery systems for spinning reserve must provide power in ranges of $10 \mathrm{~s}$ and $100 \mathrm{~s}$ of megawatts for time periods of 30 minutes. Generation outages that require spinning reserve occur about
20 to 50 times per year. These outages occur randomly.

The figure at the top of the page illustrates the generation capacity of a utility on a typical week in which a significant failure occurs; the balloon shows the detail of the capacity loss and the gradual return of the utility's generating capacity. The figure at the bottom of the page shows the battery system response to the utility need; the positive peak in the graph is the battery discharging to meet load demand; the negative peak is the battery recharge time during off-peak hours.

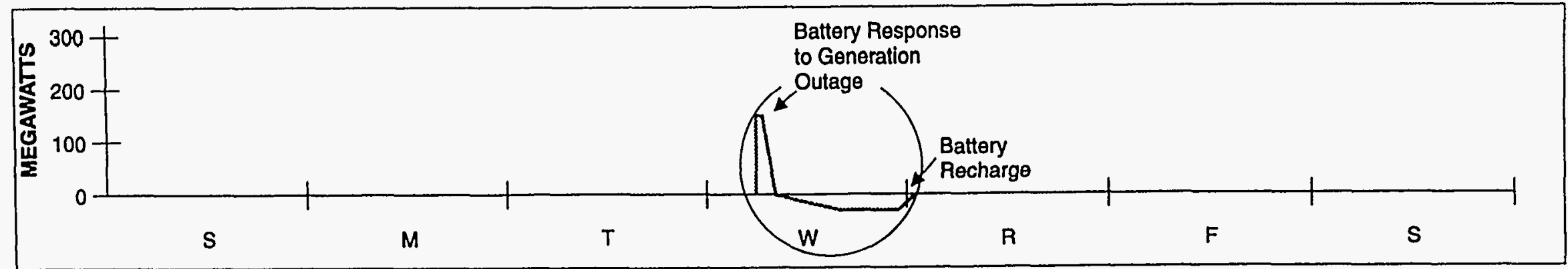

Battery System Operation to Prevent Interruption of Service During Generation Capacity Outage. 


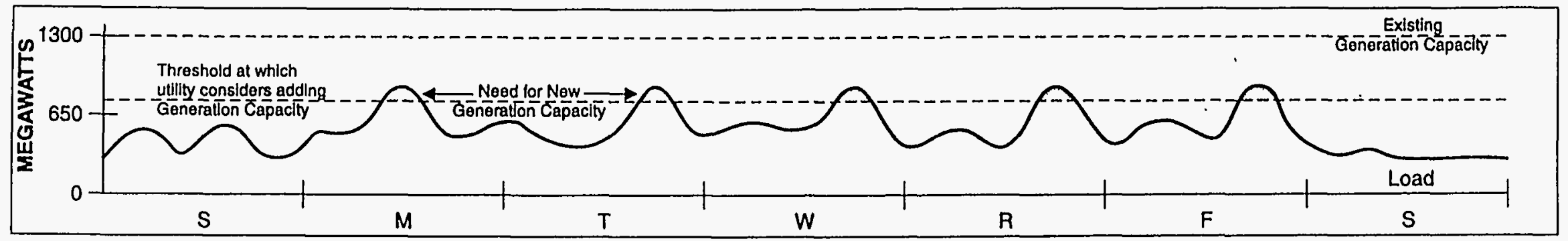

Utility Load Shape Showing Daily Peaks that Batteries can Reduce Below the Threshold that Demands Purchase of New Generating Capacity

\section{Generation Capacity Deferral}

Over time, electrical demand grows and utilities increase generation capacity to meet customers' needs. When a utility's demand-peak approaches its capacity, high procurement and construction costs, increased regulation, and opposition to siting for generation plants become significant issues. The plot on the right shows growing load demand and need for additions. Battery storage systems can help utilities to temporarily meet growing demands and defer costly generation capacity additions.
With a battery system, a utility can store power during low demand times, and deliver power when the need is greatest. Although operation of the battery system is similar to operation for load leveling, the benefit in this application is deferral of increased generating capacity; load leveling may occur as a secondary benefit to a utility with battery storage for capacity deferral. A battery system to defer installation of new generating capacity requires power in the $10 \mathrm{~s}$ to $100 \mathrm{~s}$ of megawatts, and must have 2 to 4 hours of storage capacity. The frequency of battery system operation depends upon the peaking characteristics of the particular utility, and could range from very few to hundreds of cycles per year. System operation would be most frequent during daily high-load periods during seasonal peaks. The figure at the top of this page illustrates the utility load shape for a utility with little margin between demand and existing generation capacity. Peak load exceeds the utility-defined threshold percentage of generation capacity on all weekdays.

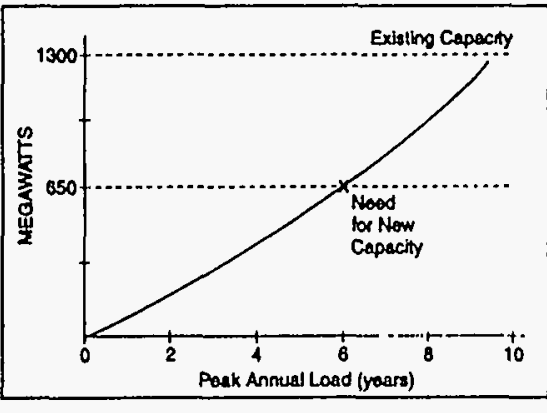

The figure at the bottom of the page shows the battery discharge during peak load times to bring the demand on generation capacity below the threshold. Battery recharge accurs during off-peak hours.

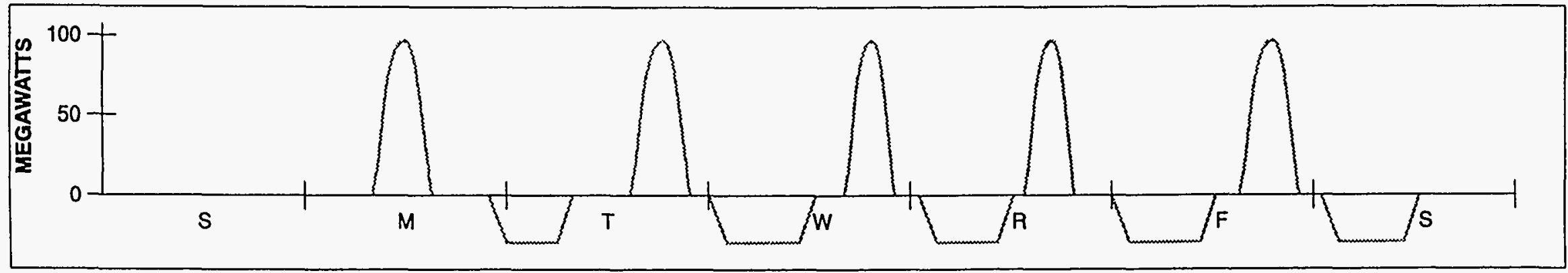

Battery System Operation to Reduce Peaks below the Threshold that Demands Purchase of New Generating Capacity. 


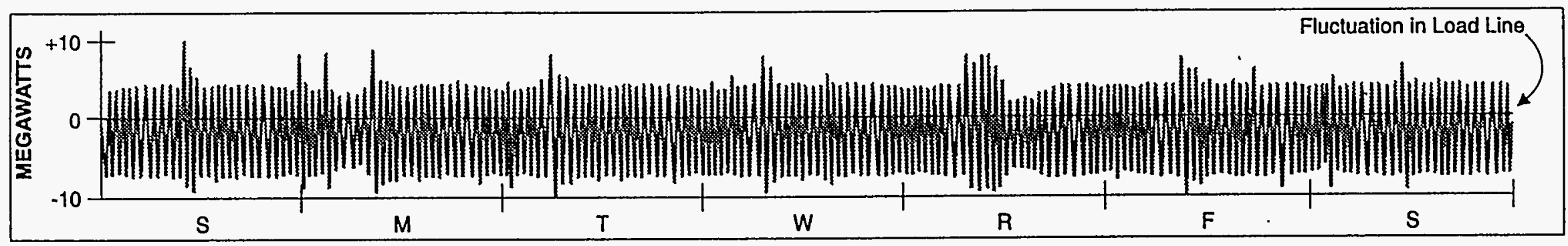

Imbalance Between Utility Power Production and Neighboring Utilities

\section{Area/Frequency Regulation}

In an isolated utility, large changes in electrical load affect the operating speed of generators at power plants. Operating speeds that differ too much from 60 cycles per second $(\mathrm{Hz})$ can damage the generators and produce electricity that does not match the $60 \mathrm{~Hz}$ requirements of electrical devices in the United States.

To regulate frequency, utilities can install battery systems that discharge to meet rising load, and charge when loads fall-off. In this way, the battery protects the generator from the fluctuation in load, and prevents subsequent frequency variations.
Interconnected utilities not only strive to regulate the frequency of their power output, but also have ties with other utilities on the grid that add complexity to the task of regulating power. In addition to experiencing fluctuations in load demand from their own customers, interconnected utilities can experience unwanted power transfer to and from utilities in the neighboring area.

To achieve such area regulation, battery systems also respond to changing load conditions. Only, for this application, battery operation prevents unplanned, unwanted transfer of power between utilities on the grid. Both frequency regulation and area regulation require battery systems in the 10 s of megawatts. Both applications require about 1 hour of storage to ensure that the battery can deliver and accept power during the frequent, shallow charging and discharging that would occur during the 250 weekdays that the battery system would operate. During low demand periods, when other power sources can provide frequency and area control, and the battery system would be inactive. The figure at the top of the page shows unscheduled power imbalances between one utility's power output and the power level of neighboring utilities on the grid. The figure at the bottom of the page, and the blow-up at right, show the battery system

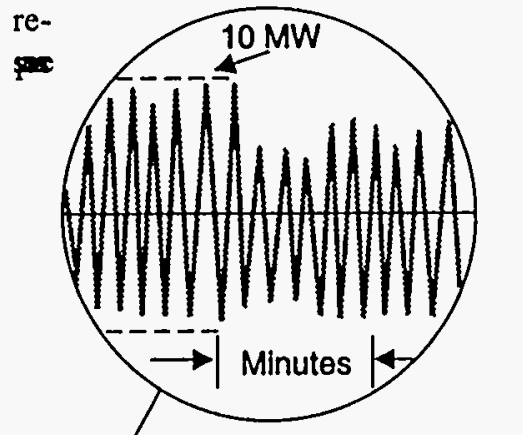

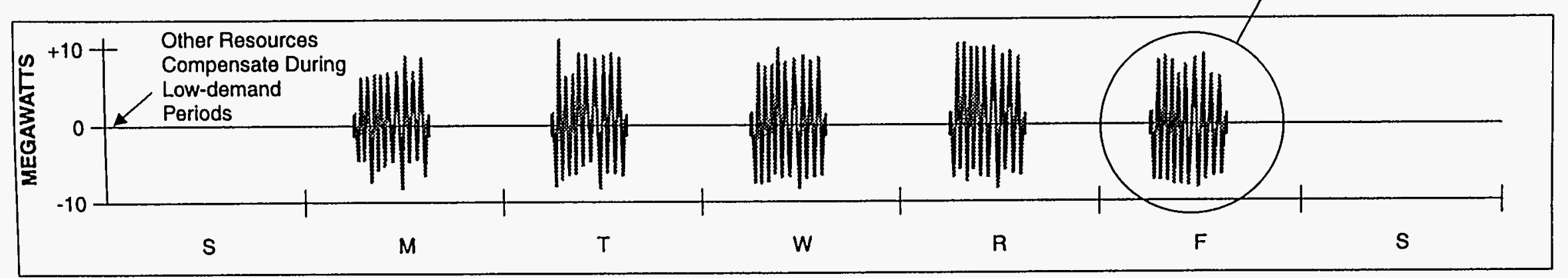

Battery System Power Output to Balance Utility Power Production with Neighboring Utilities. 


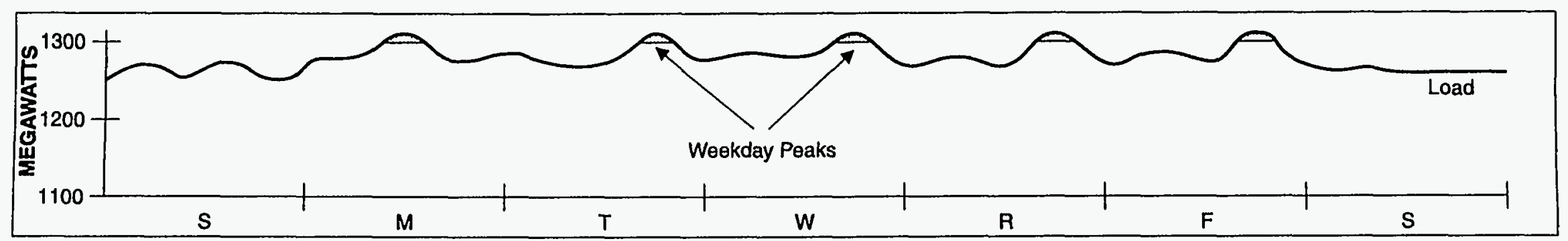

Utility Load Shape to Demonstrate Shifting Renewables Power Output to Meet Daily Peaks

\section{Renewable Applications}

Battery systems have several potential applications for renewable systems. In one near-term application, a battery system can help to deliver renewable energy at times when it is most needed. By storing power from renewable energy systems that produce power at times that do not coincide with the utility system demand peak, the owner of the renewable resource can deliver power at peak utility demand times, and create "coincident peaks" between utility demand and the renewables supply. Because utjlities will pay a higher rate for renewable energy delivered on peak, renewable power delivered during the utility peak has greater economic value.

Another near-term renewable system application for battery storage takes energy from a source with variable power, and delivers reliable, constant power on demand. Because utilities must guarantee the amount of power they have available, such power "firming" makes variable renewable sources more viable, and adds to their economic value.

The battery system for either application would be in the $1 \mathrm{~s}$ of megawatts. The battery would need storage capacity in the 1 to 4 hour range. For coincident peaking, the battery system would discharge about 250 times per year, during weekday utility peaks. For power firming, the battery would charge and discharge randomly, as renewable energy sources wax and wane.

The figure at the top of this page shows the utility load shape with daily peaks in the afternoon and early evening. The figure at the bottom of the page shows the battery system response to deliver renewable power at times that coincide with daily peak demand. The renewable resource illustrated in this example is wind, a variable power resource that generally peaks during the night.

In the long term, a utility economy with a significant percentage of renewable power may require storage capacity of days to weeks to ride through periods with cloudy skies or windless days. However, this application is still on the horizon of utility battery storage deployment.

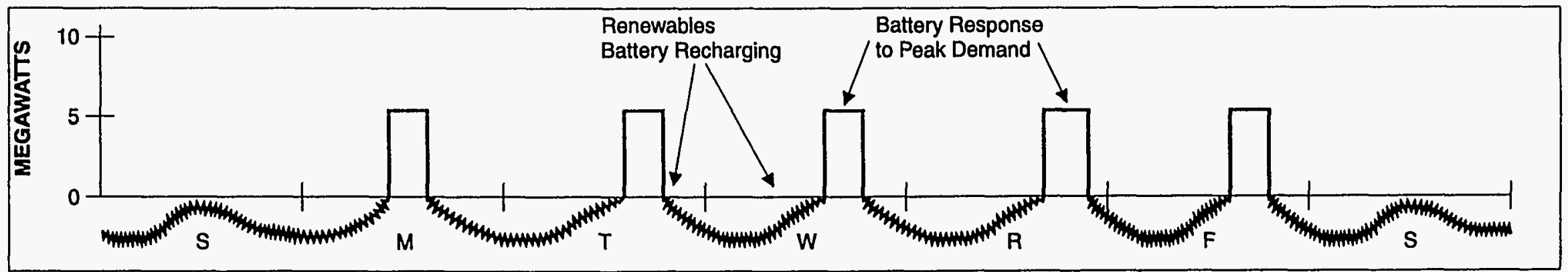

Battery System Operation to Store Renewables Energy and Deliver During Peak Demand Times. 


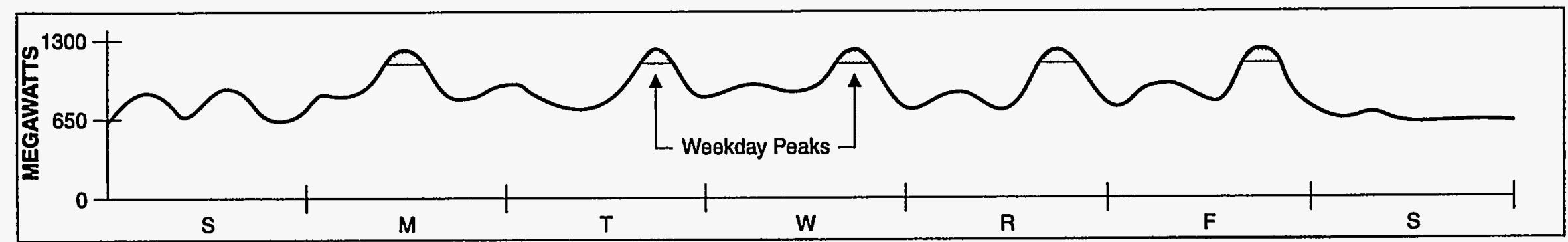

Utility Load Shape Showing Daily Peaks and the Amount of Peak Reduction Batteries Might Achieve

\section{Load Leveling}

During peak load times, utilities often need to operate costly combustion-turbine generating units to meet customer demands. With battery storage, utilities can store electricity produced by inexpensive base-loaded units during off-peak hours, and discharge power during peak demand times. "Leveling" the load demand in this way allows utilities to improve profitability by selling power produced during offpeak times at premium on-peak rates.

\section{Although load leveling was}

the first application that utilities recognized for battery energy storage, the differences in the marginal cost of generation during peak and off-peak periods for many utilities are quite small. Therefore, load leveling is generally a secondary benefit that utilities derive from a battery storage system installed for applications that offer greater economic benefits.

Load leveling applications require battery systems in the $100 \mathrm{~s}$ of megawatts. The systems must have up to 4 hours of storage capac- ity. For utilities without a seasonal impact on demand, a load-leveling system would operate on weekdays (250 days per year). For utilities that experience seasonal peaking that makes demand during some months of the year much higher than the demand in other months, load-leveling battery systems might operate much less frequently.

Operation would be clustered during seasonal peaking months.

The figure at the top of this page shows a typical utility load shape, and the amount of peak- reduction that a load-leveling battery system might achieve. The figure at the bottom of the page shows battery discharge to meet daily utility peaks, and recharge during off-peak hours. The battery system would flatten or level the shape of the utility curve.

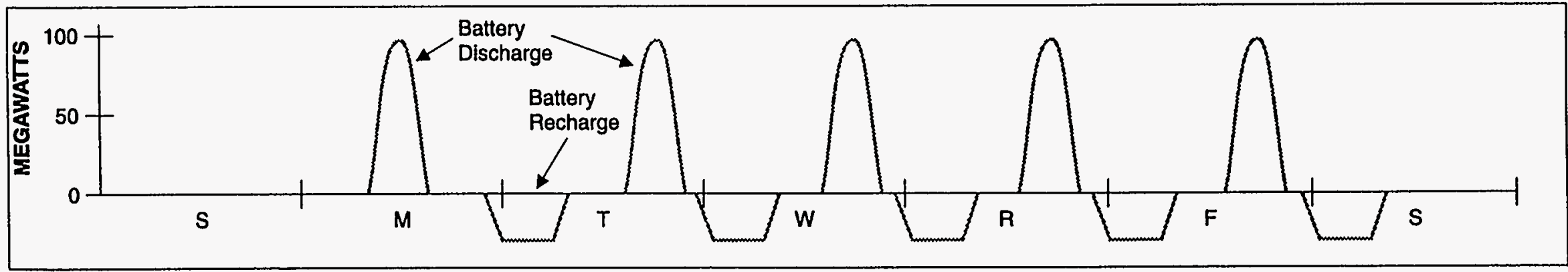

Battery System Operation to Level Daily Utility Load Peaks. 


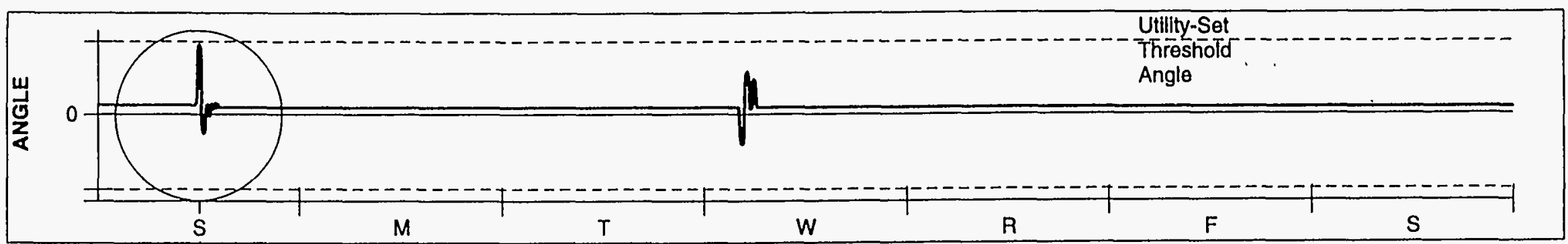

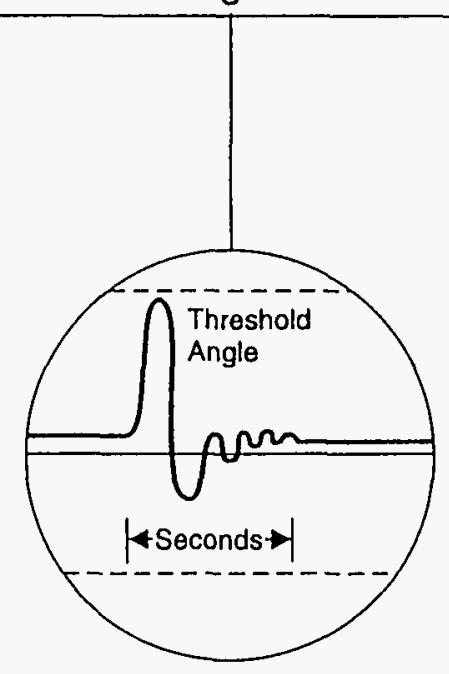

Many events in routine utility operation can cause instability in transmission systems. Events as common as customers switching loads, lightning striking, and genera-

Rotor Angle Displacement between the Generation-End and Load End of a Transmission Line

\section{Transmission Line Stability}

tors going on or off line cause gener- the system. ators in the system to fall out of sync with the rest of the system. The difference between phase angle of a generator and the phase-angle of the load-end of the transmission line measures the synchronization and stability of the system. If the difference between the angles is too large, and the utility cannot quickly (within a few cycles) damp unstable oscillations, the power system can collapse. In this very undesirable circumstance, the utility must shut down and restart its equipment to resynchronize
Battery systems can help utilities to maintain synchronous operation of their systems by discharging to provide power, and charging to absorb power as system loading conditions change. Battery systems for transmission line stability require power in the 100 s of megawatt range, have a self-commutated converter and have enough storage capacity to discharge at full power for up to 30 seconds. Battery system operation would occur about 100 times annually.
The figure at the top of the page illustrates two instances of transmission line instability; both events take the generator away from. synchronous operation with the system, toward an angle that could cause system collapse. The figure at the bottom of the page shows the battery system discharging 100 megawatt pulses into the system to counter instabilities. The balloon at the left shows an expanded time scale of the first transient event, and the generator's return' to stable operation after the battery pulse.

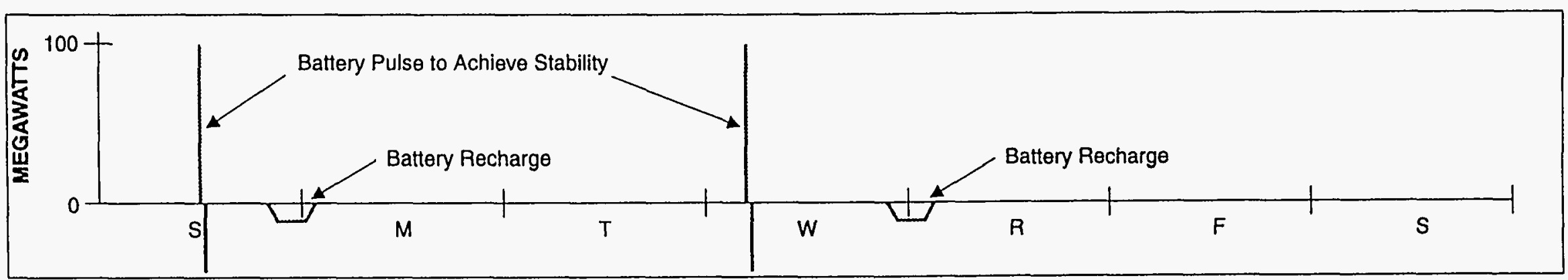

Battery System Operation to Provide Pulses of Power to Damp Unstable Oscillations in Rotor Angle Displacement. 


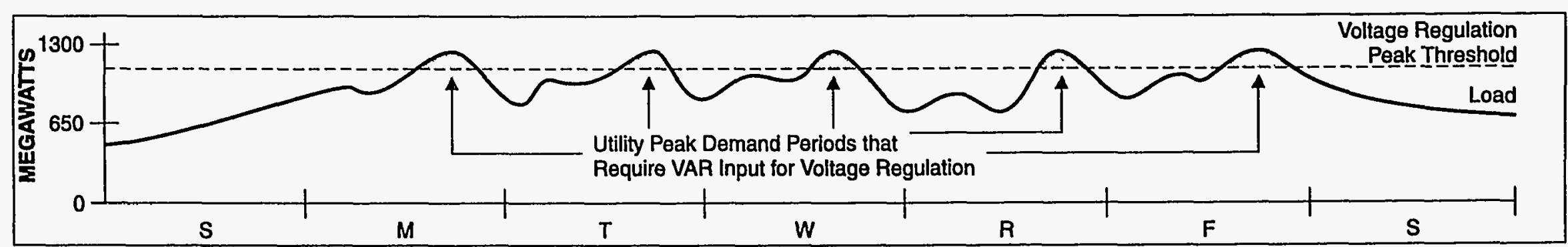

Utility Load Shape for a Randomly Selected Week Showing Peak Demand Periods

\section{Voltage Regulation} impedance in transmission lines causes the voltage at the generation-end of a line to be greater than voltage at a load location at the other end of the line. To offset this effect, utilities inject reactive power and maintain the same voltage at all locations on the line. Traditionally, fixed and switched capacitors have provid-

ed the reactive power (VARs) necessary for voltage regulation. A battery storage system that a utility has
Without corrective measures,

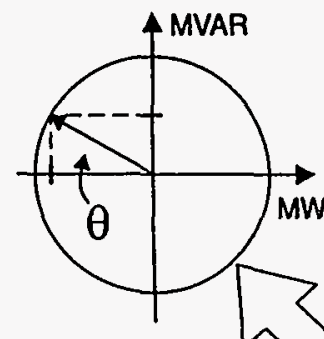

installed for some other primary application can provide VARs to the system to augment existing capacitors and replace capacitors planned for future installation.

A battery system can provide VARs during discharge, charge, or inactivity. For this reason, utilities can use battery systems in megawatt sizes (that have other primary functions in the utility) to achieve mega VARs. The battery system for voltage regulation must provide mega VARs for 15 minute intervals

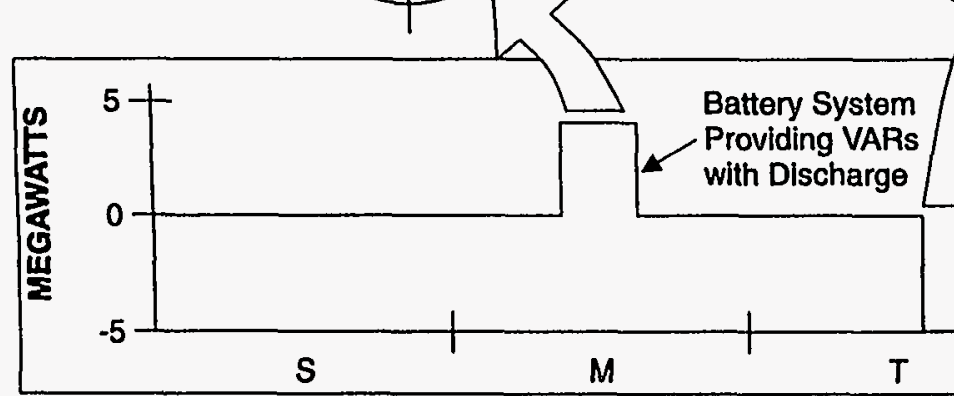
voltage regulation of $1 \mathrm{~s}$ of during daily load peaks (250 times per year). The converter must be selfcommutated.

The figure at the top of this page illustrates high-demand times that might require voltage regulation. The figure at the bottom of this page shows battery operation to provide VARs during discharge, charge, and inactivity. The circular plots associ-
Electrical Engineering texts discuss real and reactive power, and explain VAR-W circular diagrams). As inferred by these plots, the relative magnitudes of VARs and Ws that the system provides are not independent, and the inverter must be large enough to provide VARs while discharging at full 


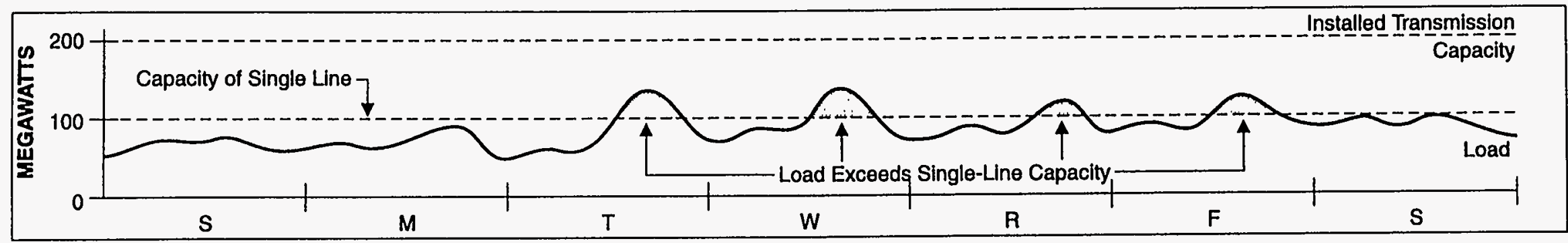

Transmission Capacity and Load on a Randomly Selected Week with Two Transmission Capacity Interruptions

\section{Transmission Facility Deferral}

When growing demand for electricity approaches the capacity of a transmission system, utilities add new lines and transformers. Because load grows gradually, new facilities are larger than necessary at the time of their installation, and utilities under-utilize them during their first several years of operation. To defer a line or transformer purchase, a utility can employ a battery storage system until load demand will fully utilize a new transformer.

Utilities sometimes define the demand at which they need to add transmission facilities as the load at which the transmission system can continue full operation in the event of the loss of one line or transformer. In the example in the figures above and at the right, the utility has applied this evaluation technique to two 100-MW transmission lines. One power line can carry the entire load during a period of low demand. However, during a high demand time, a single line cannot provide the power needed. Although the transmission capacity does not satisfy the evaluation criterion, existing demand would not fully utilize a third line. The utility could meet the load demand with a battery system, and defer an expensive facilities upgrade.

The figure below shows battery system operation to help a single transmission line to meet peak demand. Operation would occur 5 to 20 times per year, mostly during seasonal peaks, (when heavy load demand on the lines is more likely). The power requirement for this application would be in 10 s of megawatts. The battery would need to provide for 2 to 4 hours of storage.

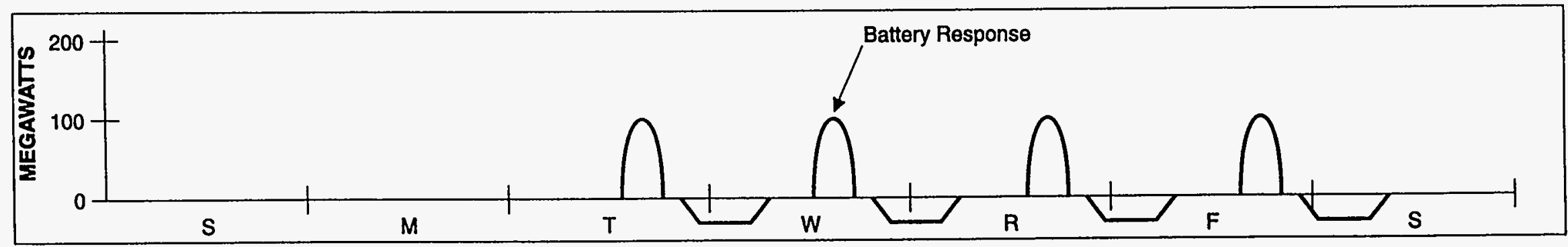

Battery System Operation to Prevent Interruption to Customer Service. 


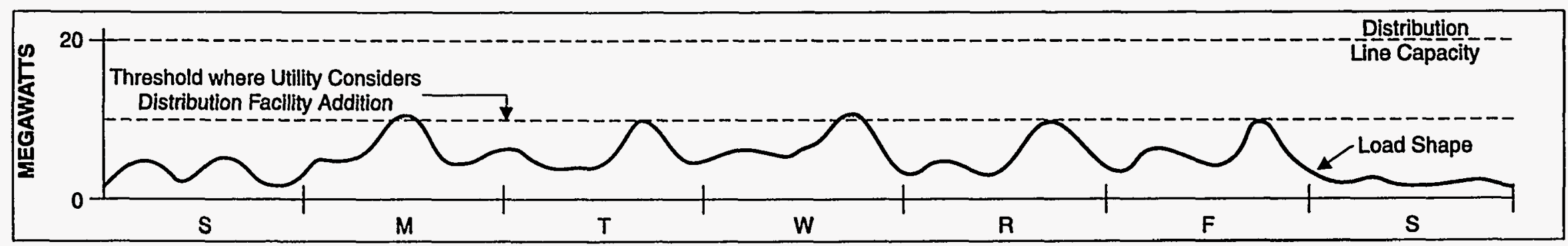

Distribution Line Capacity that cannot Meet All Daily Peaks of Distribution Line Load

\section{Distribution Facility Deferral}

As load demand approaches the capacity of distribution facilities, utilities add new lines and transformers. The figure at the right illustrates demand growth that approaches the installed distribution capacity. Because demand will continue to grow, utilities install facilities that exceed existing load demands. Therefore, utilities under utilize expensive distribution facilities during their first several years in service. With battery energy storage systems, utilities can help existing distribution facilities to meet current load demands, and defer the purchase and installation of new distribution facilities until the demand fully justifies new facilities.

A battery system to defer installation of new distribution capacity requires power in the $1 \mathrm{~s}$ of megawatts, and must provide 1 to 3 hours of storage. In a typical distribution facility, the battery system would operate about 30 times per year. The system would operate most frequently during daily high-load periods that occur during seasonal peaks.

The figure at the top of this page illustrates the distribution load shape for a utility with an insufficient margin between demand and existing distribution capacity. Load exceeds the capacity on one day. The figure at the bottom of the page shows the battery discharge to meet the demand, and recharge during off-peak hours.
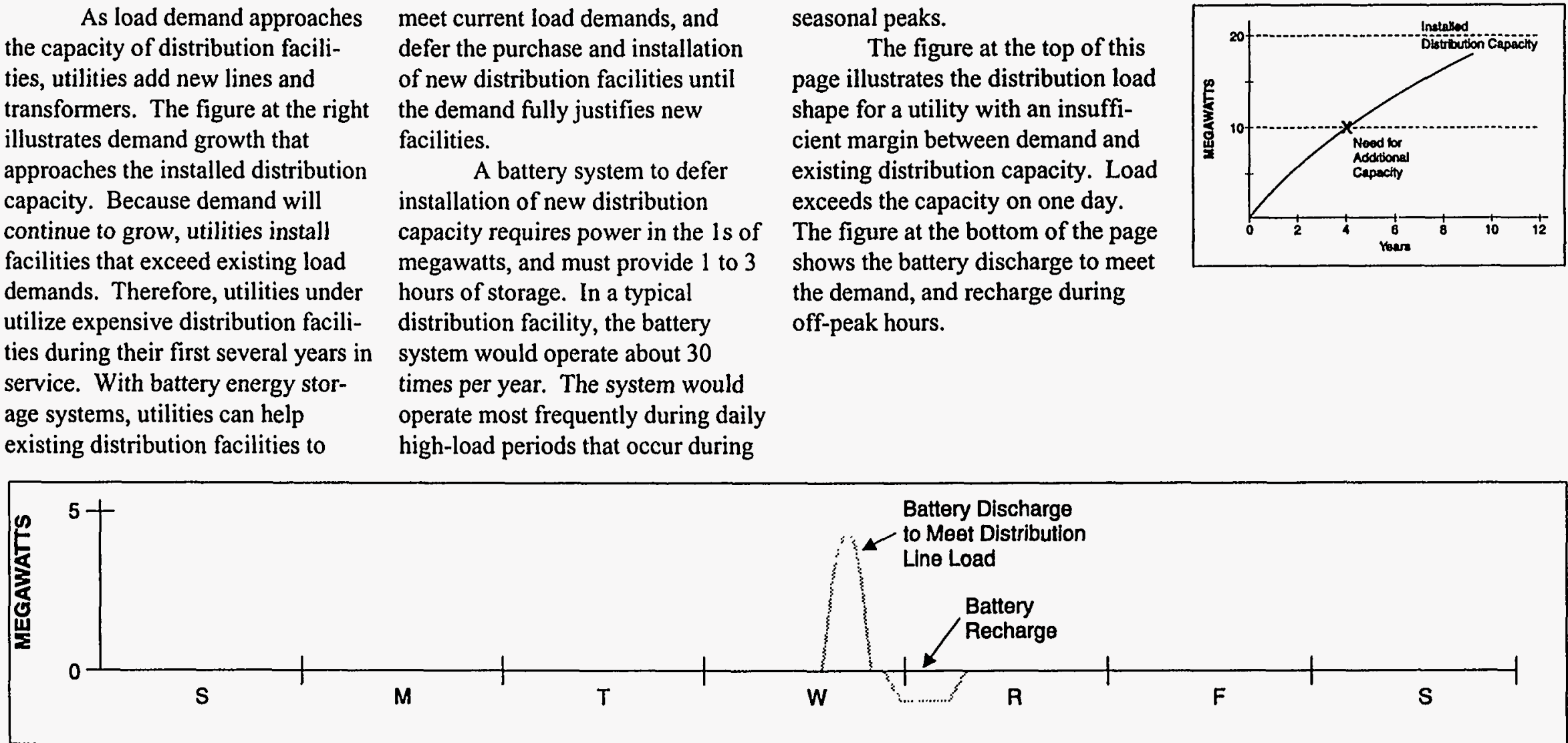

Battery System Operation to Meet Daily Distribution Line Load Peaks and Defer New Capacity Installation. 


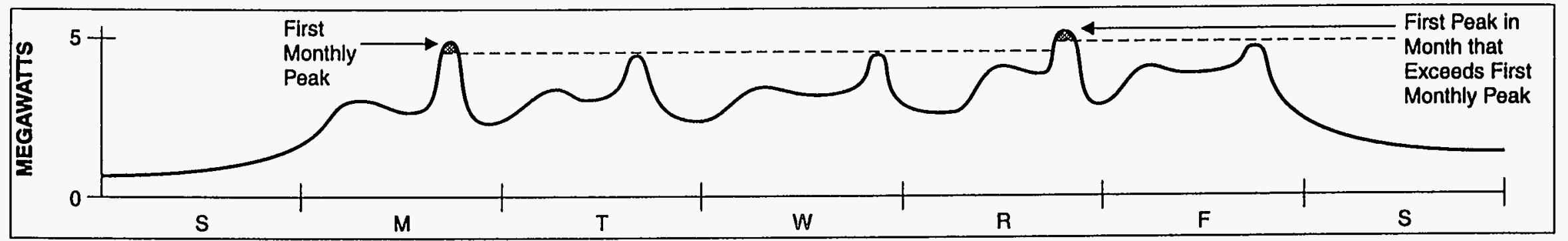

Customer Load Shape with Successive Peak Shaving to Reduce Monthly Peak Demand Charge

\section{Custoner Demand Peak Shaving}

Utilities typically charge commercial and industrial customers a monthly fee (peak-demand charge) based on the highest power drawn during the month. By reducing peak demand, or "peak shaving," customers can significantly reduce peak demand charges. The figure at the top of this page illustrates a way that customers typically reduce monthly demand peaks. At the beginning of the month, the battery system shaves the first peak and notes the reduced peak power level. Then, the battery system remains idle until power demand exceeds the reference value stored during the previous peak shaving event. When load exceeds the reference value, the system discharges the battery to shave this peak, and again notes the maximum power that the utility provided to the customer. This process continues until the end of the month, when the system resets.

The figure at the top of the page illustrates the customer's load during the first week in a billing period; peak shaving occurs twice. The battery system shaves the first monthly peak, stores the maximum load value (represented by the lowest dashed line), and waits for load exceed the stored value to operate a second time. The figure at the bottom of the page shows the battery operation with discharge for peak saving and recharge during off-peak hours. In this application, the battery system would discharge 7 or 8 times per month, or about 100 times per year. The system size would be in the 1 megawatt range. The battery would need 1 to 2 hours of storage capacity. A battery system installed for peak shaving could also allow a customer to take advantage of interruptible or timeof-use rates that many utilities offer.

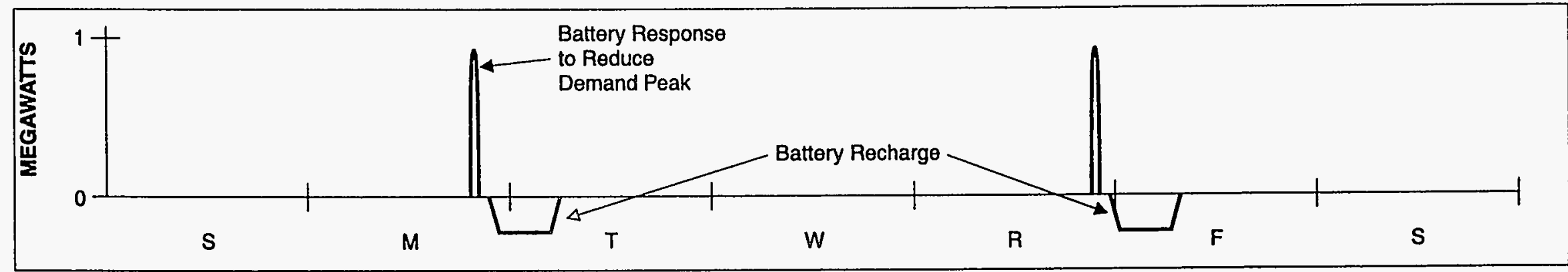

Battery System Operation to Shave Successive Customer Demand Peaks. 


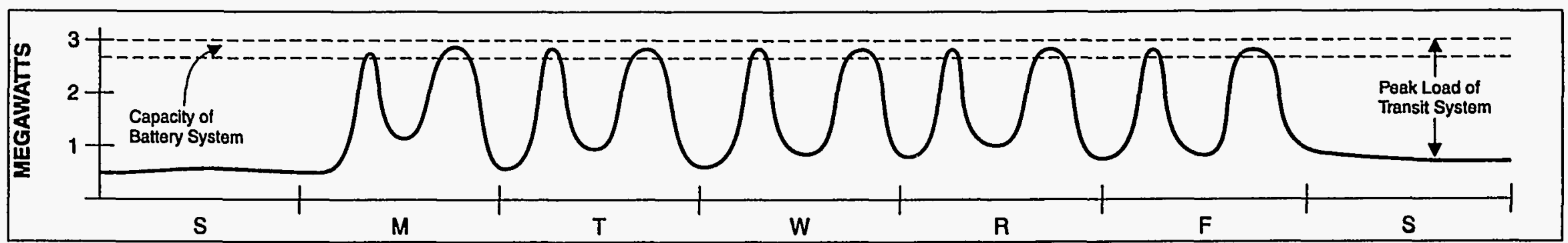

Transit System Demand on Substations along a Twenty-mile Span

\section{Transit System Peak Shaving}

Transit system peak shaving is a special case of customer peak shaving. For transit systems, demand peaks typically occur twice daily, during the morning and evening rush hours. These rushhour peaks on subway or electric trolley and train systems can be quite large and expensive. Because transit systems pay a monthly fee based on the highest power drawn during the month, they want to reduce peak demands. Battery Storage can help.

Transit system peaks are large enough to create significant swings in utility loading. For this reason, utilities share interest in reducing transit system peaks.

Several utilities have decided to assist their transit system customers in evaluating battery storage systems. Unlike an industrial peak shaving battery system, a battery system for a transit application must operate on all weekdays to shave the demand peak that occurs during the utility's highest demand-charge time (for this utility - the afternoon), or twice each weekday to shave both peaks. The battery system for transit system peak reduction would be in the 1 megawatt, 1 to 2 hour size range, and would operate between 250 and 500 times annually.

The figure at the top of the page illustrates the transit system demand on a typical week. The figure at the bottom of the page shows a $200 \mathrm{KW}$ battery system's operation to shave both weekday peaks.

Another application for battery storage in transit systems is regenerative braking. In this application, batteries store the energy that transit cars expend when they brake to decelerate. The energy, stored instead of lost, is available to the system upon demand. Depending on the system design, the battery storage system could be on-board and transit-authority owned, or in or near a station and utility-owned.

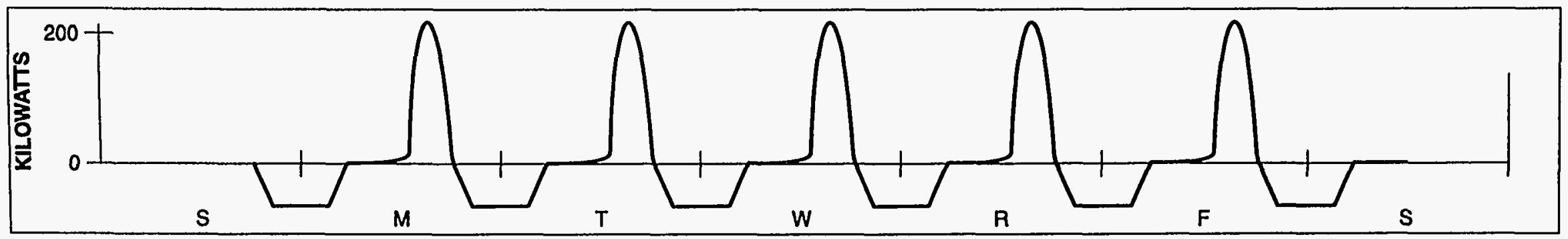

Battery System Operation to Shave Peak at one Substation During Maximum Demand in On-Peak Charging Region. 


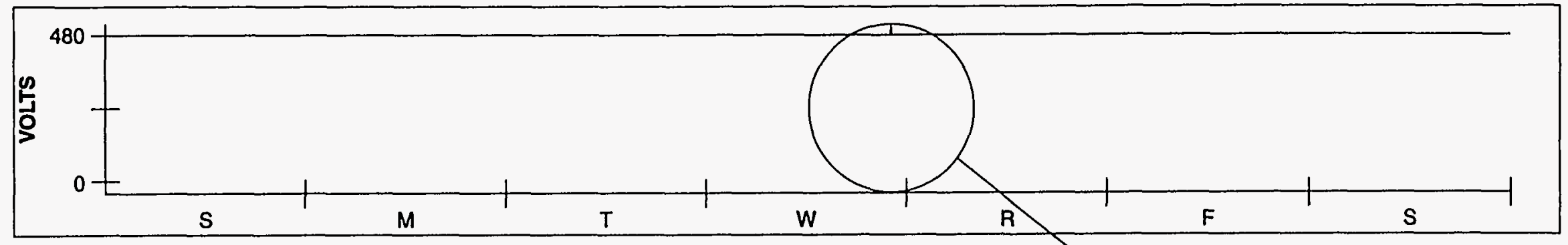

Voltage Delivered to a Small Utility Customer on a Typical Week with Small Voltage Amplitude Fluctuations

\section{Reliability - Small Customer}

Small industrial and commercial customers often operate sensitive electronic systems that cannot tolerate voltage sags, voltage spikes, or loss of power. The duration of a power sag may be only one or two cycles (1/60th of a second) but its effects can be costly. Microprocessors on assembly lines and computers shut down and production and data processing suffer.

To protect these electronic devices and the product and data and product they control, customers can install battery systems to prevent power sags, spikes, and failures from ever reaching their equipment. Battery system installation determines how the system operates.

If a battery system operates in parallel with the load, the battery system disconnects load from a faulted power supply, and provides power until normal utility voltage returns. To operate in the absence of a utility signal, the converter must be self-commutated.

If a battery system operates in series with the load, the power conversion system always operates. However, battery provides power only when voltage sags and interruptions occur. This battery system would require 100 s of kilowatts, and 15 minutes of storage.

Voltage sags, spikes, and power loss typically occur about 10 times a year. A self-commutated converter is necessary to reform 60 $\mathrm{Hz}$ voltage.

The figures on this page demonstrate the second way to install the battery system in which the converter operates all of the time and the battery provides or absorbs backup power as needed.

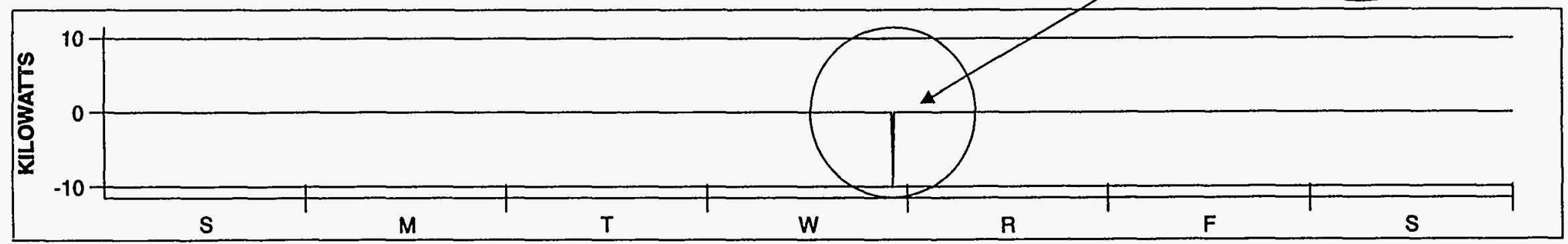

Battery System Operation to Bring Voltage at Small Customer Site to Desired Amplitude. 


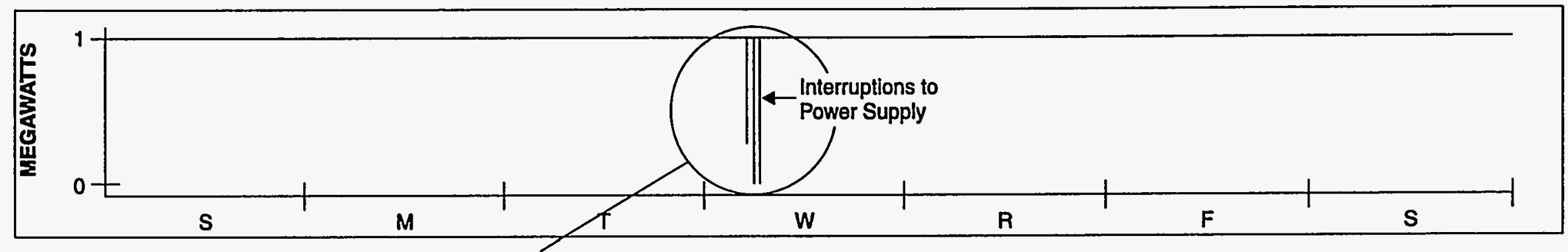

Power Supplied to a Large Utility Customer with Potentially Costly Interruptions

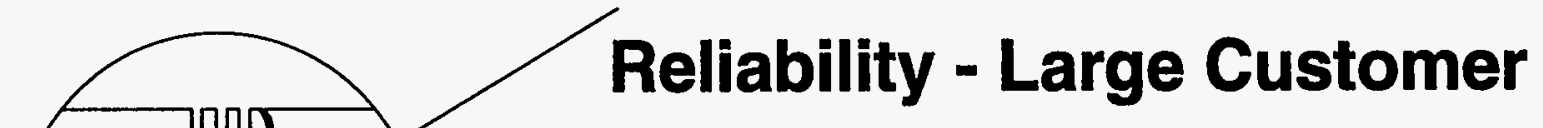

from the electric utility and provide all of the power required to maintain normal operations. The system would provide utility-grade, 60 -Hertz power in much less than one cycle (1/60th of a second). The rapid response would protect the customer from power loss and the associated costs. The battery would provide power until discharged to its limit or until the utility restores power. After power restoration, the battery would recharge.

$$
\text { The battery system would be in }
$$
costly intermuptions in production and productivity for large commercial and industrial customers. A battery system can increase power reliability for a large utility customer by providing all of the power that the customer demands during a utility outage. In the event of a fault, the fullycharged battery system would automatically disconnect the customer's building and derive additional utility benefits from storage. The inverter must be self- the absence of a utility signal. The battery system would require 1 to 2 hours of storage, depending on the customer's requirements and the number of length of outages expected in that utility service territory (typically $<10$ times annually). The same battery system could also improve customer power quality during voltage sags or spikes. In this application, the system would disconnect the customer from the utility when voltage goes above or below certain set-points (e.g., $\pm 10 \%$ of nominal). As in the previous case, the system would provide all of the customer's power during the fault and switch back to utility power when the utility voltage returns to normal. commutated in order to deliver power in

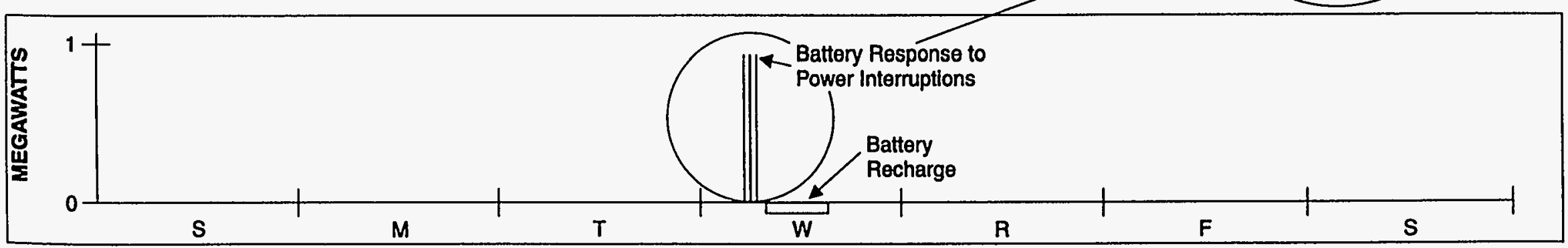

Battery System Operation to Briefly Support Interrupted Power Supply at Necessary Power Level. 


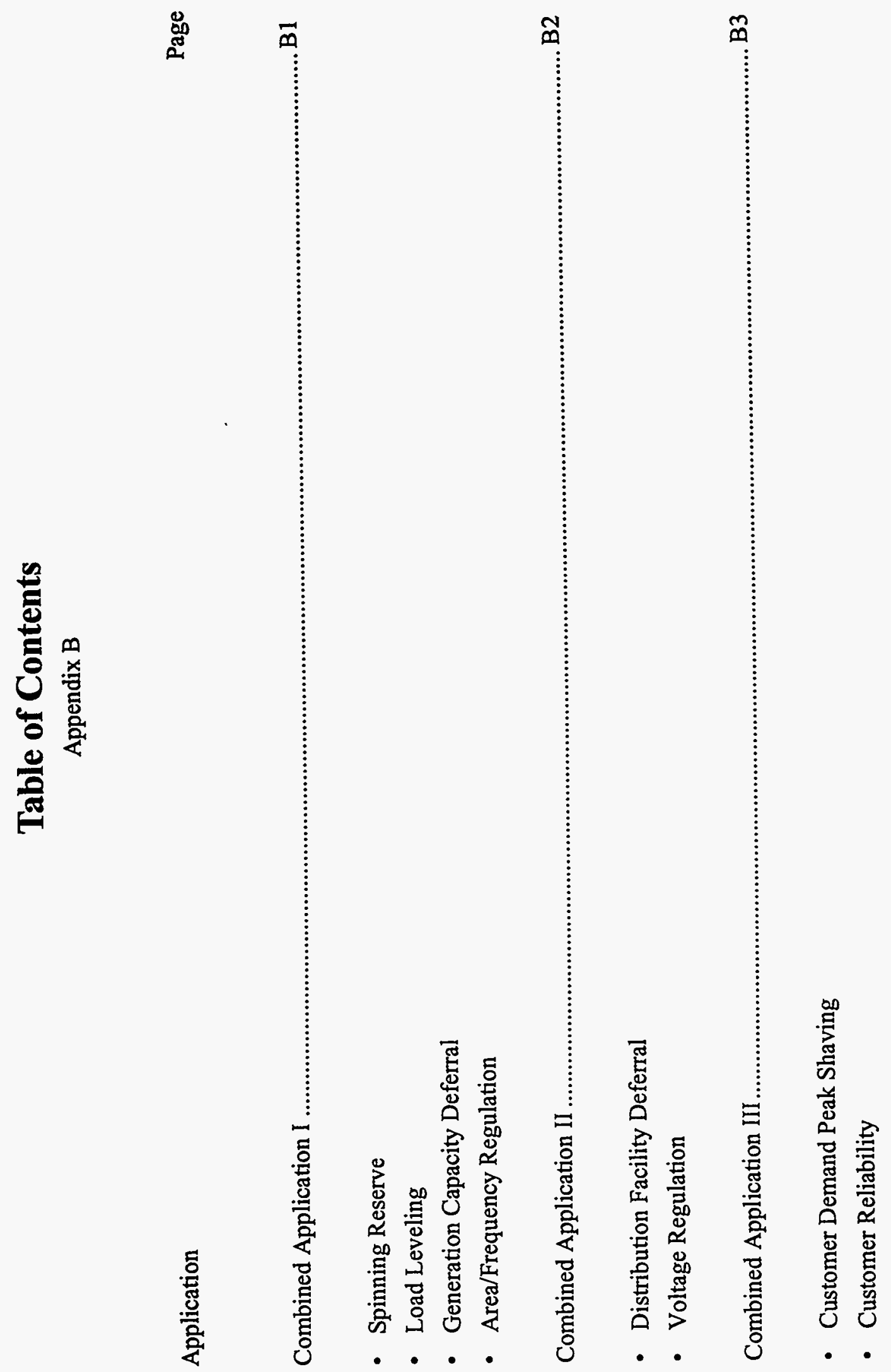


APPENDIX B: SCHEMATIC ILLUSTRATIONS OF BATTERY SYSTEM RESPONSES TO THREE GROUPS OF MULTIPLE APPLICATIONS 


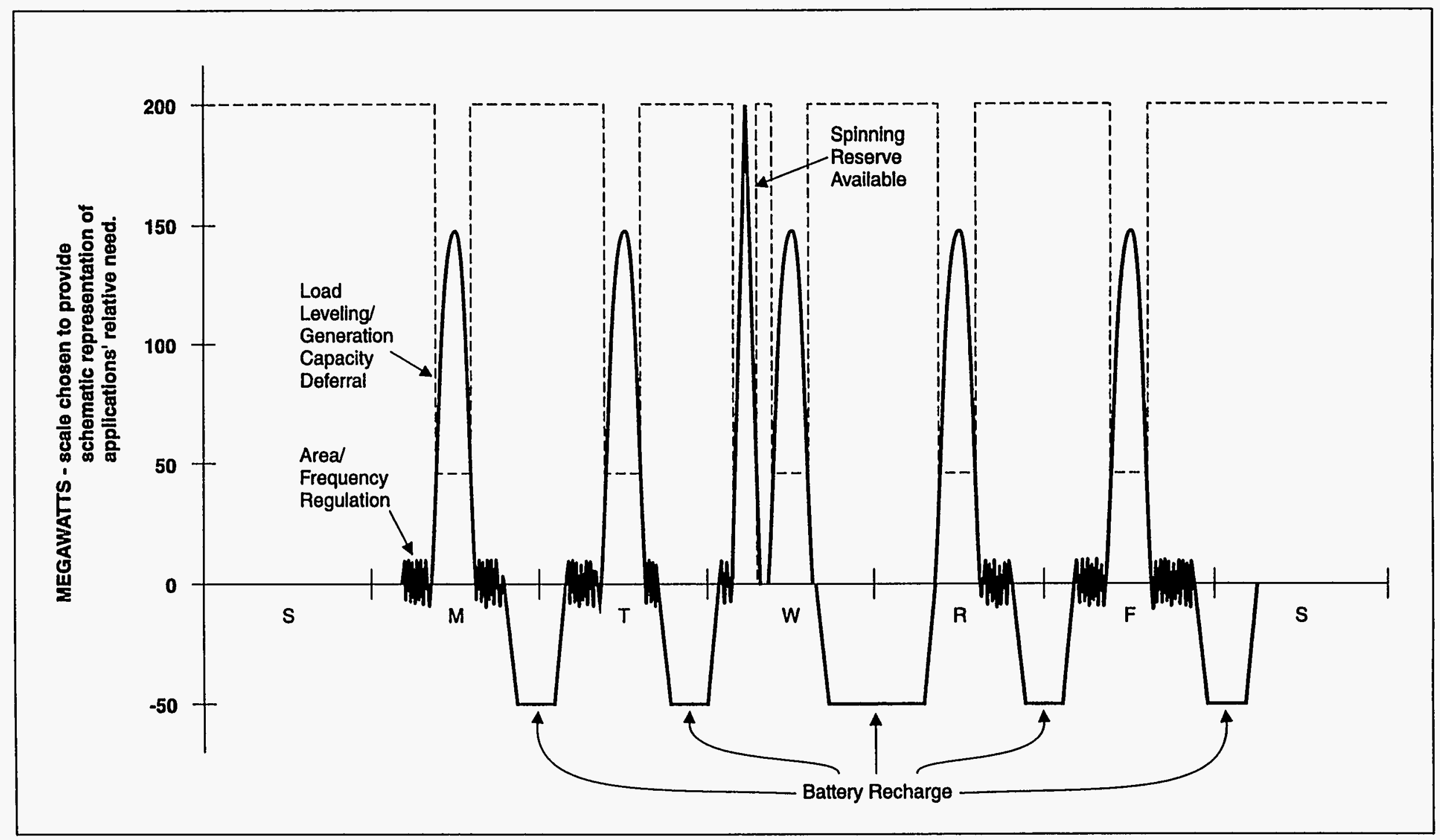

Utilities that have simultaneous need for Load Leveling and Generation Capacity Deferral will size batteries

appropriately. At times when the battery provides Spinning Reserve, other applications will not be available to the utility. 


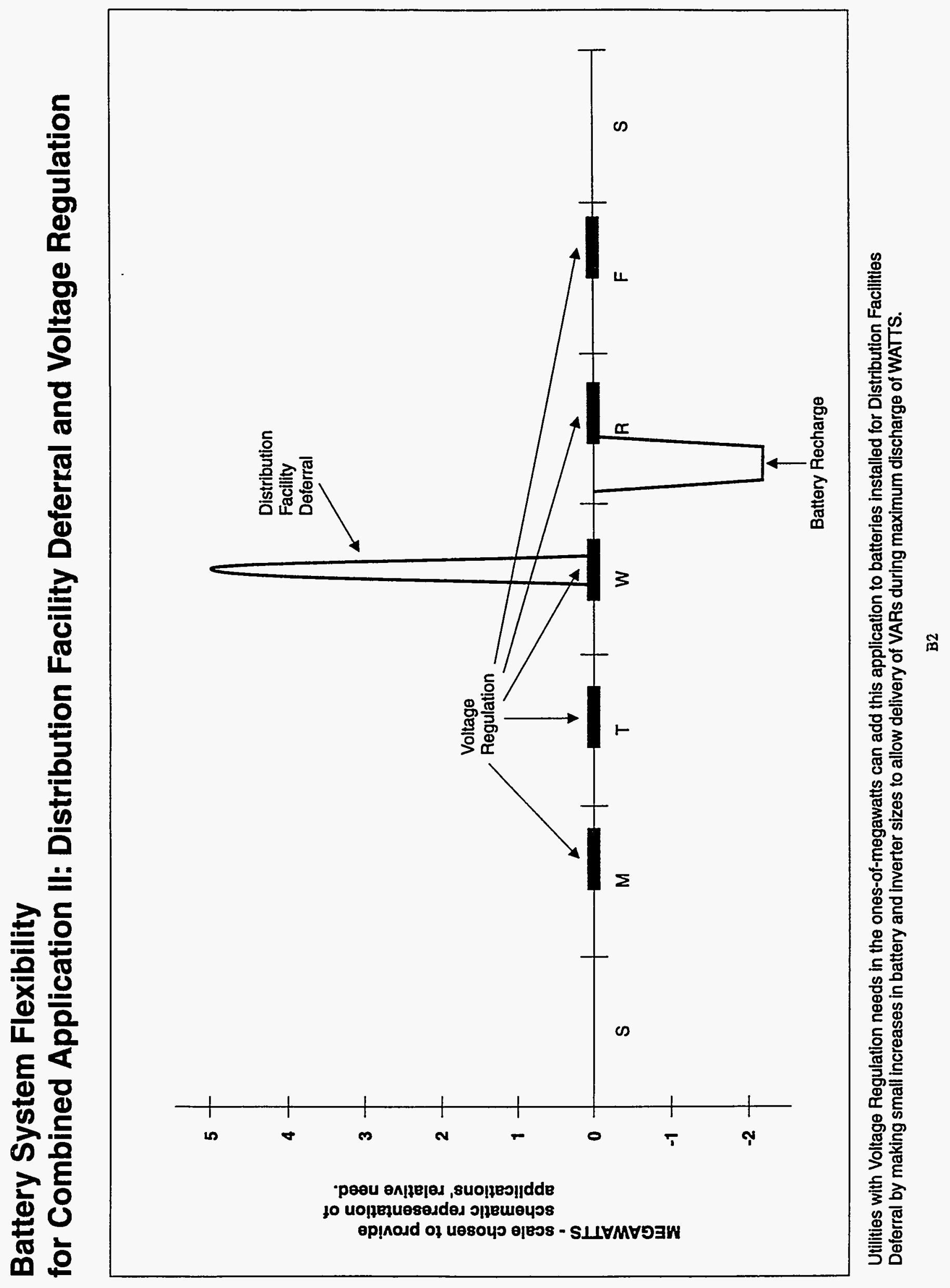




\section{Battery System Flexibility for}

\section{Combined Application III: Customer Reliability and Customer Demand Peak Shaving}

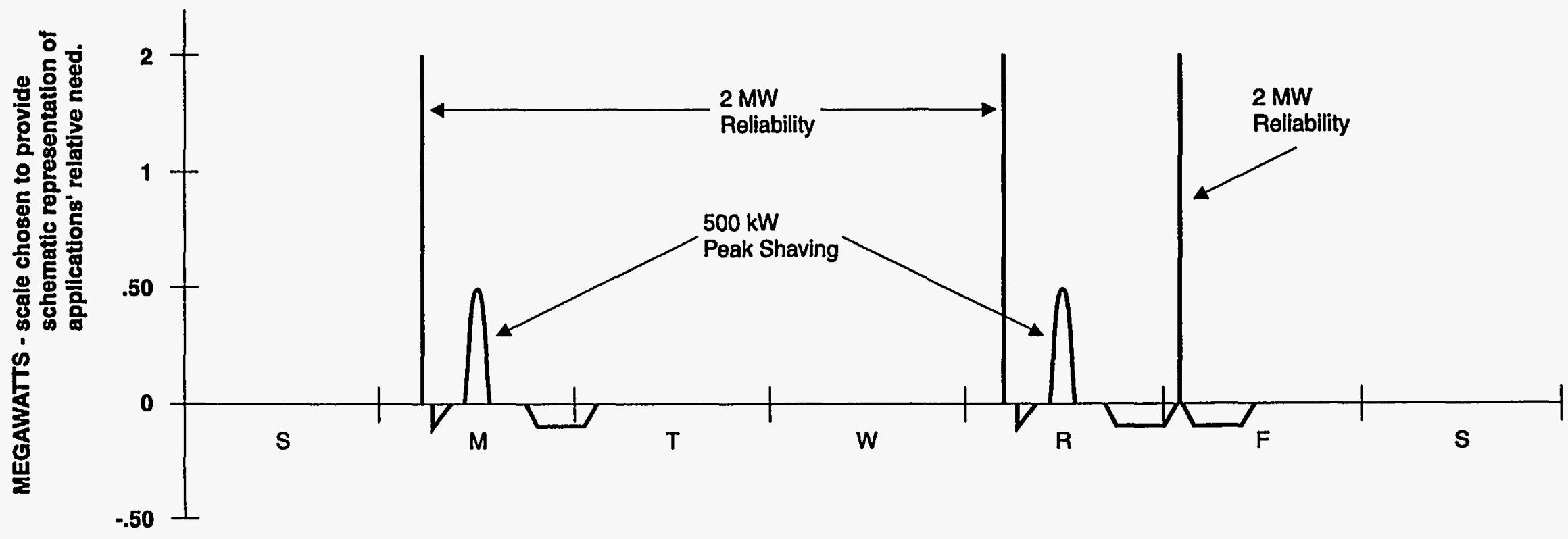

This example illustrates a particular case in which a utility employs a battery system to meet a $500 \mathrm{~kW} / 2 \mathrm{hr}$ Peak Shaving Demand and to ensure power rellability to 2 $\mathrm{MW}$ for durations of seconds to 15 minutes. Although a fault is instantaneous, and requires only seconds of ride-through, facilities with safety specifications that require manual reset after a fault may require minutes of storage. 


\section{Distribution}

ABB Power T\&D Co., Inc. (2)

Attn: P. Danfors

H. Weinrich

1100 Cornwall Road

Monmouth Junction, NJ 08852

Abacus Controls, Inc.

Attn: G. O'Sullivan

80 Readington Road

Somerville, NJ 08876

AC Battery Corporation

Attn: R. Flemming

2080 Energy Drive

P.O. Box 325

East Troy, WI 53120

American Electric Power Service Corp.

Attn: C. Shih

1 Riverside Plaza

Columbus, OH 43215

Argonne National Laboratories (3)

Attn: C. Christianson

W. DeLuca

K. Myles

CTD, Building 205

9700 South Cass Avenue

Argonne, IL 60439

Arizona Public Service

Attn: R. Hobbs

P.O. Box 5399

Phoenix, AZ 85072

AT\&T Bell Laboratories

Attn: K. Bullock

3000 Skyline Drive

Mesquite, TX 75149

AT\&T Energy Systems

Attn: M. Bize

3000 Skyline Drive

Mesquite, TX 75149

Bechtel

Attn: W. Stolte

P.O. Box 193965

San Francisco, CA 94119-3965
Bonneville Power Administration

Attn: J. Ray

Routing EO

P.O. Box 3621

Portland, OR 97208

C\&D Charter Power Systems, Inc.

Attn: S. Misra

3043 Walton Road

P.O. Box 239

Plymouth Meeting, PA 19462-0239

California State Air Resources Board

Attn: J. Holmes

Research Division

P.O. Box 2815

Sacramento, CA 95812

Chugach Electric Association, Inc.

Attn: T. Lovas

P.O. Box 196300

Anchorage, AK 99519-6300

Consolidated Edison (2)

Attn: M. Lebow

N. Tai

4 Irving Place

New York, NY 10003

Corn Belt Electric Cooperative

Attn: R. Stack

P.O. Box 816

Bloomington, IL 61702

Decision Focus, Inc.

Attn: S. Jabbour

650 Castro Street, Suite 300

Mountain View, CA 94041

Delco-Remy

Attn: M. Hinga

P.O. Box 2439

Anderson, IN 46018

Delco-Remy

Attn: R. Rider

7601 East 88th Place

Indianapolis, IN 46256 
Delmarva Power

Attn: R. Nigro

Christiana Building

252 Chapman Road

P.O. Box 6066

Newark, DE 19714-6066

Division of Energy

Attn: A. Khan

333 W. 4th Ave., Suite 220

Anchorage, AK 99501-2341

Doug Danley

18131 Metz Dr.

Germantown, MD 20874

Eagle-Picher

Attn: J. Zagrodnik

$12500 \mathrm{~W}$. Silver Spring Drive

P. O. Box 591

Milwaukee, WI 53201-0591

Eagle-Picher Industries

Attn: J. DeGruson

C \& Porter Street

Joplin, MO 64802

East Penn Manufacturing Co., Inc.

Attn: C. Elium

Deka Road

Lyon Station, PA 19536

Electrochem Storage Systems, Inc.

Attn: D. Feder

35 Ridgedale Avenue

Madison, NJ 07940

Electric Power Research Institute (5)

Attn: J. Birk

S. Chapel

S. Eckroad

R. Schainker

R. Shumard

3412 Hillview Avenue

P. O. Box 10412

Palo Alto, CA 94303

Electrochemical Engineering Consultants, Inc.

Attn: P. Symons

1295 Kelly Park Circle

Morgan Hill, CA 95037
Electrotek Concepts, Inc.

Attn: H. Barnett

P.O. Box 16548

Chattanooga, TN 37416

Electrotek

Attn: C. Smith

2111 Wilson Blvd., Suite 323

Arlington, VA 22201

Eltech Research Corporation

Attn: E. Rudd

625 East Street

Fairport Harbor, OH 44077

Energetics, Inc. (4)

Attn: J. Badin

H. Lowitt

J. Hurwitch

P. Taylor

7164 Columbia Gateway Drive

Columbia, MD 21046

Energy Systems Consulting

Attn: A. Pivec

41 Springbrook Road

Livingston, NJ 07039

Exxon Research Company (2)

Attn: P. Grimes

R. Bearden

P.O. Box 536

1900 East Linden Avenue

Linden, NJ 07036

Firing Circuits, Inc.

Attn: J. Mills

P.O. Box 2007

Norwalk, CT 06852-2007

General Electric Company (2)

Attn: E. Larson

D. Swann

Building 2, Room 605

1 River Road

Schenectady, NY 12345

General Electric Drive Systems

Attn: D. Daly

1501 Roanoke Blvd.

Salem, VA 24153 
Giner, Inc.

Attn: A. LaConti

14 Spring Street

Waltham, MA 02254-9147

GNB Battery Technologies

Industrial Battery Company (3)

Attn: S. Deshpande'

G. Hunt

J. Szymborski

Woodlake Corporate Park

829 Parkview Blvd.

Lombard, IL 60148-3249

Hawaii Electric Light Co.

Attn: C. Nagata

P.O. Box 1027

Hilo, HI 96720

Hughes Aircraft Company

Attn: R. Taenaka

P.O. Box 2999

Torrance, CA 90509-2999

ILZRO

Attn: J. Cole

P.O. Box 12036

Research Triangle Park, NC 27709

Integrated Power Corp.

Attn: J. Adelman

7524 Standish Place

Rockville, MD 20855

Johnson Controls Battery Group, Inc. (4)

Attn: P. Eidler

R. Miles

T. Ruhlmann

W. Tiedeman

5757 N. Green Bay Avenue

P. O. Box 591

Milwaukee, WI 53201

Kenetech Windpower, Inc.

Attn: B. Erdman

6952 Preston Avenue

Livermore, CA 94550

Lawrence Berkeley Laboratory (3)

Attn: E. Cairns

K. Kinoshita

F. McLarnon

University of California

One Cyclotron Road

Berkeley, CA 94720
Lawrence Livermore National Laboratory (2)

Attn: R. Koopman, L-644

J. Cooper, L-369

P.O. Box 808

Livermore, CA 94551

J. Meglen

P.O. Box 3232

Oakton, VA 22124

Metlakatla Power \& Light

Attn: D. Pierce

P.O. Box 359

Metlakatla, AK 99926

N.E.T.S.

Attn: T. Neubauer

P.O. Box 32584

Juneau, AK 99803

National Renewable Energy Laboratory (3)

Attn: R. McConnell

J. Ohi

N. Rau

1617 Cole Blvd.

Golden, CO 80401-3393

New York Power Authority

Attn: B. Chezar

1633 Broadway

New York, NY 10019

New York Power Authority

Attn: D. Levin

123 Main Street

White Plains, NY 10601

Niagra Mohawk Power Corp.

Attn: C. Burns

R\&D A-2

300 Erie Blvd. West

Syracuse, NY 13202

Northern States Power

Attn: M. Rogers

414 Nicollet Mall

Minneapolis, MN 55401

Oak Ridge National Laboratory (3)

Attn: B. Hawsey, Bldg. 3025, MS-6040

J. Stoval, Bldg. 3147, MS-6070

J. VanCoevering, Bldg. 3147, MS-6070

P.O. Box 2008

Oak Ridge, TN 37831 
Oglethorpe Power Company (2)

Attn: K. Scruggs

C. Ward

2100 E. Exchange Place

P.O. Box 1349

Tucker, GA 30085-1349

Omnion Power Engineering Corporation (3)

Attn: H. Meyer

D. Porter

F. Ruf

P.O. Box 879

East Troy, WI 53120

Pacific Gas \& Electric (3)

Attn: G. Ball

B. Norris

R. Winter

3400 Crow Canyon Road

San Ramon, CA 94583

Pacific Northwest Laboratory (2)

Attn: J. DeSteese, K5-02

K. Drost

Battelle Blvd.

Richland, WA 99352

Power Cell Corporation (2)

Attn: G. Keresteci

R. Orr

1 Memorial Drive

Cambridge, MA 02142

Power Technologies, Inc.

Attn: P. Prabhakara

1482 Erie Blvd.

P.O. Box 1058

Schenectady, NY 12301

Power Technologies, Inc.

Attn: H. Clark

775 Sunrise Ave.

Suite 210

Roseville, CA 95661

Public Service Co. of NM

Attn: E. Arguello

R. Braziel

Alvarado Square

Albuquerque, NM 87158

Puerto Rico Electric Power Authority

Attn: W. Torres

G.P.O. Box 4267
R\&D Associates

Attn: J. Thompson

2100 Washington Blvd.

Arlington, VA 22204-5706

RMS Company

Attn: K. Ferris

87 Martling Ave.

Pleasantville, NY 10570

Robicon Corporation

Attn: A. Maruschak

100 Sagomore Hill Road

Pittsburgh, PA 15239

Sacramento Municipal Utility District

Attn: L. Wittrup

6201 S. Street

Sacramento, CA 95817

Salt River Project

Attn: H. Lundstrom

MS PAB 357, Box 52025

Phoenix, AZ 85072-2025

San Diego Gas \& Electric Company (2)

Attn: T. Nelson

J. Wight

P.O. Box 1831

San Diego, CA 92112

W. J. Schafer Associates

Attn: S. Schoenung

303 Lindbergh Avenue

Livermore, CA 94550-9551

R. K. Sen \& Associates

Attn: R. Sen

3808 Veazey Street NW

Washington, DC 20016

Silent Power, Inc.

Attn: J. Rassmussen

163 West 1700 South

Salt Lake City, UT 84115

Silent Power, Inc. (2)

Attn: W. Auxer

A. Koenig

489 Devon Park Drive

Suite 315

Wayne, PA 19087 
Silent Power, Ltd.

Attn: M. McNamee

Davy Road, Astmoor

Runcorn, Cheshire

UNITED KINGDOM WA7 1PZ

Solarex

Attn: G. Brawn

630 Solarex $\mathrm{Ct}$.

Frederick, MD 21701

Southern California Edison (2)

Attn: A. Rodriguez

R. Scheffler

2244 Walnut Grove Avenue

P.O. Box 800

Rosemeade, CA 91770

SRI International

Attn: C. Seitz

333 Ravenswood Ave.

Menlo Park, CA 94025

Stuart Kuritzky

347 Madison Avenue

New York, NY 10017

Superconductivity, Inc.

Attn: J. Emerick

2114 Eagle Drive

Middleton, WI 53562

Texas Utilities Electric

Attn: J. Fangue

Skyway Tower

400 N. Olive, L.B.81

Dallas, TX 75201

United Engineers and Contractors

Attn: A. Randall

700 South Ash St.

P.O. Box 5888

Denver, CO 80217

University of Missouri - Rolla

Attn: M. Anderson

112 Electrical Engineering Building

Rolla, MO 65401-0249

University of New Mexico

Attn: S. Kelly

School of Law

1117 Stanford NE

Albuquerque, NM 87131-1431
University of Wisconsin - Madison

Attn: D. Divan

Dept. of Electrical \& Computer Eng.

1415 Johnson Drive

Madison, WI 53706

U.S. Department of Energy

Attn: T. Petersik

Energy Information Administration

EI-531 FORSTL

Washington, DC 20585

U.S. Department of Energy

Attn: M. Gunn

Office of Energy Management

EE-14 FORSTL

Washington, DC 20585

U.S. Department of Energy (21)

Attn: R. Eaton (20)

N. Rossmeissl

Office of Energy Management

EE-142 FORSTL

Washington, DC 20585

U.S. Department of Energy

Attn: A. Landgrebe

Office of Propulsion Systems

EE-321 FORSTL

Washington, DC 20585

U.S. Department of Energy

Attn: G. Buckingham

Albuquerque Operations Office

Energy Technologies Division

Albuquerque, NM 87115

R. Weaver

777 Wildwood Lane

Palo Alto, CA 94303

Westinghouse STC

Attn: H. Saunders

1310 Beulah Road

Pittsburgh, PA 15235

W. R. Grace \& Company

Attn: S. Strzempko

62 Whittemore Avenue

Cambridge, MA 02140

Yuasa-Exide

Attn: N. Magnani

P.O. Box 14145

Reading, PA 19612-4145 
Yuasa-Exide

Attn: F. Tarantino

P.O. Box 14205

Reading, PA 19612-4205

Zaininger Engineering Co., Inc.

Attn: H. Zaininger

1590 Oakland Road, Suite B211

San Jose, CA 95131

MS 0513 H. Schmitt (Org. 2000)

MS 1070 R. Bair (Org. 2200)

MS 0613 R. Clark (Org. 2206)

MS 0613 L. Lachenmeyer (Org. 2206)

MS 0613 K. Grothaus (Org. 2222)

MS 0613 D. Doughty (Org. 2223)

MS 0613 P. Butler (Org. 2225) (30)

MS 0613 A. Akhil (Org. 2225)

MS 0613 J. Braithwaite (Org. 2225)

MS 0613 N. Clark (Org. 2225)

MS 0613 G. Corey (Org. 2225)

MS 0613 J. Freese (Org. 2225)

MS 0613 R. Jungst (Org. 2225)

MS 0214 J. Kerr, Attn: A. Phillips (Org. 10214)

MS 0735 D. Arvizu (Org. 6200)

MS 0752 T. Bickel (Org. 6213)

MS 0753 W. Bower (Org. 6218)

MS 0753 R. Bonn (Org. 6218)

MS 9103 P. Falcone (Org. 8111)

MS 9054 W. McLean (Org. 8300)

MS 9018 Central Technical Files (Org. 8523-2)

MS 0899 Technical Library (Org. 7141) (5)

MS 0619 Technical Publications (Org. 7151)

MS 0100 Document Processing for

DOEJOSTI (Org. 7613-2) (10) 